Review

\title{
New Perspectives on the Biogenesis of Viral Inclusion Bodies in Negative-Sense RNA Virus Infections
}

\author{
Olga Dolnik (D), Gesche K. Gerresheim and Nadine Biedenkopf *(D) \\ Institute for Virology, Philipps-University Marburg, 35043 Marburg, Germany; \\ dolnik@staff.uni-marburg.de (O.D.); gesche.gerresheim@staff.uni-marburg.de (G.K.G.) \\ * Correspondence: nadine.biedenkopf@staff.uni-marburg.de; +49-(0)-64212825307
}

Citation: Dolnik, O.; Gerresheim, G.K.; Biedenkopf, N. New

Perspectives on the Biogenesis of

Viral Inclusion Bodies in

Negative-Sense RNA Virus Infections. Cells 2021, 10, 1460. https://doi.org/ 10.3390/cells10061460

Academic Editors: Thomas Hoenen and Allison Groseth

Received: 19 May 2021

Accepted: 8 June 2021

Published: 10 June 2021

Publisher's Note: MDPI stays neutral with regard to jurisdictional claims in published maps and institutional affiliations.

Copyright: (C) 2021 by the authors. Licensee MDPI, Basel, Switzerland. This article is an open access article distributed under the terms and conditions of the Creative Commons Attribution (CC BY) license (https:/ / creativecommons.org/licenses/by/ $4.0 /)$.

\begin{abstract}
Infections by negative strand RNA viruses (NSVs) induce the formation of viral inclusion bodies (IBs) in the host cell that segregate viral as well as cellular proteins to enable efficient viral replication. The induction of those membrane-less viral compartments leads inevitably to structural remodeling of the cellular architecture. Recent studies suggested that viral IBs have properties of biomolecular condensates (or liquid organelles), as have previously been shown for other membraneless cellular compartments like stress granules or P-bodies. Biomolecular condensates are highly dynamic structures formed by liquid-liquid phase separation (LLPS). Key drivers for LLPS in cells are multivalent protein:protein and protein:RNA interactions leading to specialized areas in the cell that recruit molecules with similar properties, while other non-similar molecules are excluded. These typical features of cellular biomolecular condensates are also a common characteristic in the biogenesis of viral inclusion bodies. Viral IBs are predominantly induced by the expression of the viral nucleoprotein $(\mathrm{N}, \mathrm{NP})$ and phosphoprotein $(\mathrm{P})$; both are characterized by a special protein architecture containing multiple disordered regions and RNA-binding domains that contribute to different protein functions. $\mathrm{P}$ keeps $\mathrm{N}$ soluble after expression to allow a concerted binding of $\mathrm{N}$ to the viral RNA. This results in the encapsidation of the viral genome by $\mathrm{N}$, while $\mathrm{P}$ acts additionally as a cofactor for the viral polymerase, enabling viral transcription and replication. Here, we will review the formation and function of those viral inclusion bodies upon infection with NSVs with respect to their nature as biomolecular condensates.
\end{abstract}

Keywords: negative strand RNA viruses (NSV); viral inclusion bodies; biomolecular condensates; liquid-liquid phase separation (LLPS); viral replication; nucleoprotein; phosphoprotein

\section{Introduction}

As viruses are obligatory intracellular parasites, their replication cycle relies on essential processes in the infected host cell. Viruses thereby exploit and remodel the cellular architecture by inducing structural, functional, or biochemical changes to enable efficient viral replication.

During infection, many viruses induce the formation of distinct and specialized intracellular compartments that facilitate viral replication. Those specialized intracellular compartments are very heterogenous and designated as viral inclusions, inclusion bodies (IBs), viroplasms, virosomes, or viral factories and present a hallmark of viral infection [1,2]. Some of those compartments are connected directly to membranes, such as the endoplasmatic reticulum (ER) in Hepatitis $C$ virus [3,4], dengue virus [5] or severe acute respiratory syndrome coronavirus (SARS CoV) 2 [6,7] infections, lysosomes in Semliki forest virus infection [8] or mitochondria (Flock House virus) [9]. These single- and double-membrane vesicles, convoluted membranes or tubular structures are a typical feature of infection by positive strand RNA viruses [10-15]. In contrast, viral inclusions during infections with many negative-sense RNA viruses are membrane-less but still localize in special cytoplasmic areas (summarized in Figure 1). 


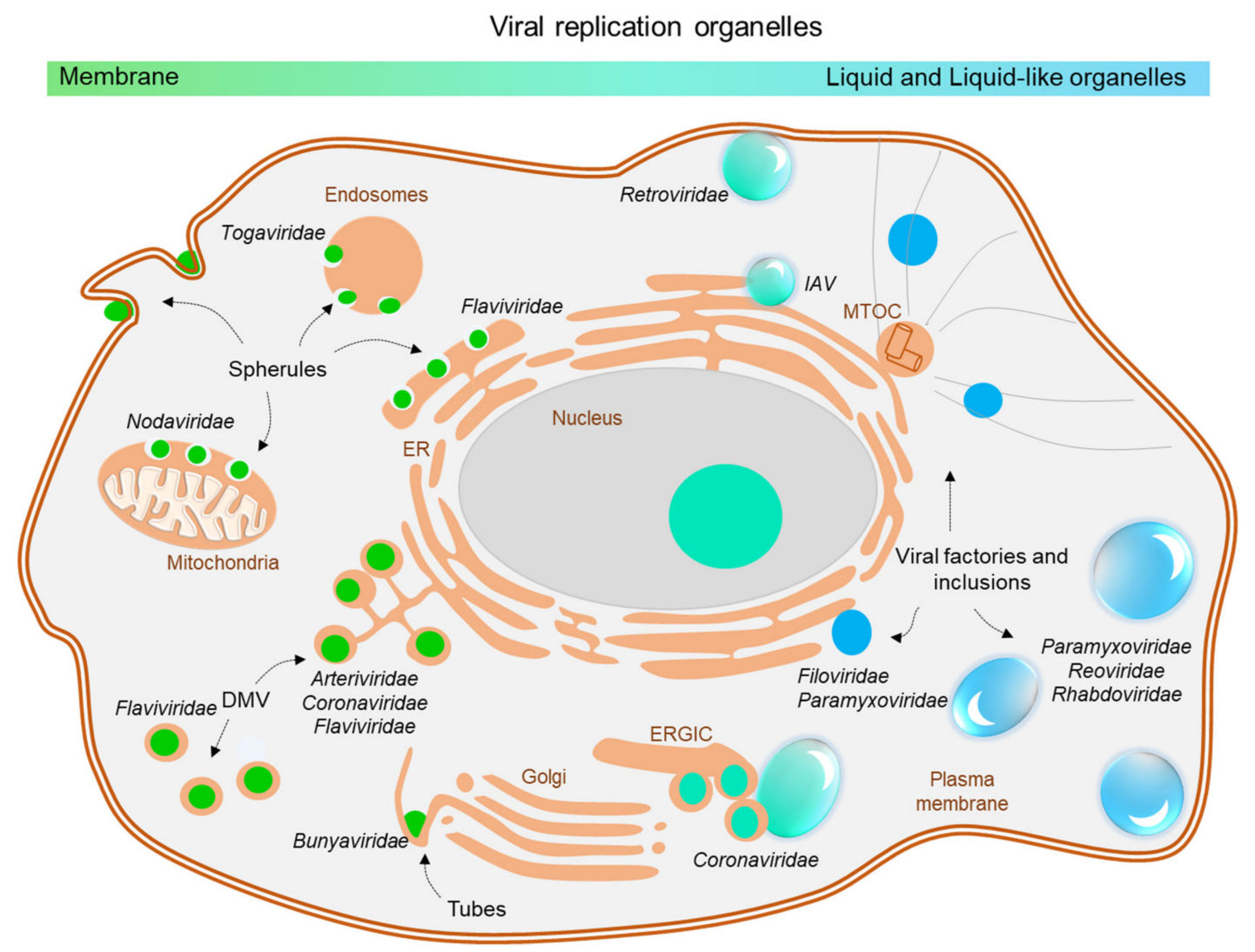

Figure 1. Overview on viral replication organelles in cells upon infection with different RNA viruses. Viral replication compartments associated with membranes are depicted in green, membrane-less compartments are indicated in blue. Those with liquid phase properties are depicted as droplets. DMV, double membrane vesicles. ER, endoplasmatic reticulum. IAV, Influenza A virus. MTOC, microtubule organizing center, ERGIC, endoplasmtic-reticulum-Golgi intermediate compartment.

Recent investigations could demonstrate that many of those IBs share common properties with liquid organelles or biomolecular condensates. Those active, biochemically functional and membrane-less cellular compartments have become an emerging interest during the last decade. Biomolecular condensates display the properties of liquids and are highly dynamic and regulated structures in the cell involved in many different biological processes [16,17]. The underlying biophysical mechanism is, in most cases, regulated by liquid-liquid phase separation (LLPS), a mechanism similar to a water-in-oil-mixture [18,19]. The emerging investigations of these highly dynamic structures lead also to a paradigm change with respect to viral IB formation and function. Typical features of biomolecular condensates like dynamics, fusion activity, and reversibility are also characteristic for viral IB formation [19-22].

Here, we will review the current state of viral IB formation and function in infections with negative-sense RNA viruses, especially with respect to the emerging field of viral inclusions with properties of biomolecular condensates.

\subsection{Biomolecular Condensates}

In the last years, the physical properties of cellular molecules as a key factor for cellular organization gained more and more interest $[16,17,22-24]$. The mechanism and localization of biochemical processes have been for long years attributed solely to membranesurrounded organelles. However, studies over the last decade have proven evidence of a cellular compartmentalization lacking a lipid boundary. Those membrane-less cellular structures are very heterogeneous in size and composition. Although they share similarities with the surrounding cytoplasm, they present separated, sometimes impenetrable cytoplasmic organelles that show a high dynamic plasticity and assemble/disassemble 
rapidly [16,25-27]. Owing to their biophysical properties that they share with liquids (like droplet fusion, surface tension, etc.), these biochemical functional compartments have been referred to as liquid (droplet) organelles or, more common in cellular biology, as biomolecular condensates [16-19,27-30]. Biomolecular condensates have been observed in different cells among eukaryots, bacteria, yeast, and archae [23,31-34]. They are ubiquitous observed across cellular compartments. In the cytoplasm, they are represented by stress granules, P-bodies, G-bodies [23,35-38] or in the nucleus, by nucleolus or Cajal bodies [39-41], for example. The main biophysical mechanism underlying the formation of biomolecular condensates is the LLPS, a mechanism similar to a water-in-oil mixture that leads to the separation of two (or even more) phases when left unperturbed [42,43]. The transition from soluble molecules to condensates (saturation concentration), liquid crystals, or aggregates is strongly regulated by thermodynamical factors like temperature, concentration, valency, and interaction strength between molecules [28,44-47]. The interphase of the different phases results intracellularly in the membrane-less boundary of biomolecular condensates that allow penetration by molecules with similar properties, while it excludes molecules with dissimilar features [20,22,43]. In cell biology, LLPS originates from protein:protein, protein:RNA, or RNA:RNA interactions that lead to the remodeling of a soluble phase into a condensated, dense phase. A key factor here is the multivalency of the molecules itself: multiple inter- and intramolecular connections that can lead to the formation of condensates with multiple interaction partners [28,29]. Certain properties of protein:protein interfaces have already been shown to drive protein phase separation: arginine-glycine-glycine/arginine-glycine (RGG/RG) motifs [48], chargecharge interactions and intrinsically disordered regions (IDRs) [49-51]. Interestingly, many IDR-containing proteins also have RNA-interaction interfaces. Under high concentration and molecular crowding, structured protein domains have also been described to drive LLPS [29,52]. Accordingly, posttranslational modifications such as phosphorylation or methylation also have a big impact on the formation of biomolecular condensates [53-56]. Expression of RNA and proteins, changes in their ratio, as well as RNA-scaffolded assembly of proteins all contribute to condensation and dynamics of LLPS in cells [35,57-59].

\subsection{Viral Replication Cycle of Negative Strand RNA Viruses (NSV)}

The members of negative strand RNA viruses (NSV) comprise viruses that have a single-stranded, negative-sense RNA genome. They can be divided into virus families that have segmented genomes such as Orthomyxoviruses, Arenaviruses, and Bunyaviruses, or into non-segmented negative-sense RNA viruses (nsNSV, also termed Mononegavirales). The latter comprises several virus families (for example, Paramyxoviridae, Bornaviridae, Rhabdoviridae, Pneumoviridae, Filoviridae) with high relevance of individual representatives as human pathogens such as Measles virus (MeV), Nipah virus (NiV), Rabies virus (RABV), Respiratory Syncytial Virus (RSV), or Marburg and Ebola virus (MARV, EBOV) [60]. These viruses share a common architecture of their genomes. The RNA genome length varies between 12 (RSV, VSV) and 19 (filoviruses) $\mathrm{kb}$ in length and contains essential untranslated regions (UTRs) at their $3^{\prime}$ - (leader) and 5' - (trailer) terminal ends important for viral transcription, replication, and encapsidation [61-65]. While the number of genes encoded by nsNSV varies among its families (from 5 to 10), the organization and relative position of the structural genes is highly conserved: 3'- leader- Nucleoprotein N-Phosphoprotein P- Matrix protein (M)- Glycoprotein (G)- RNA-dependent RNA polymerase (L for large protein)- trailer-5' (Figure 2A,B). 
A

A $\quad G$

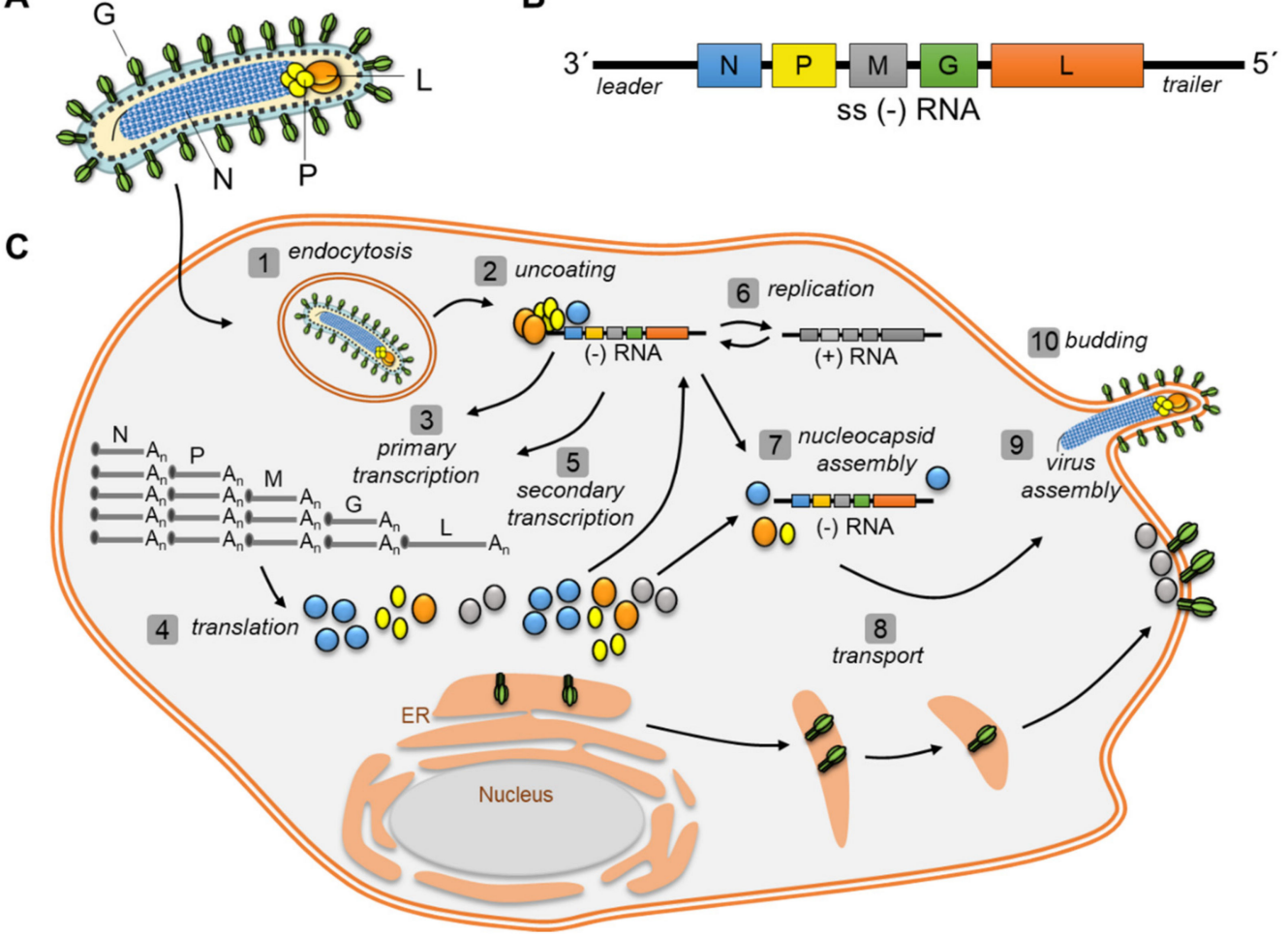

B

Figure 2. (A) Schematic diagram of a NSV particle. (B) General genome organization of a NSV. (C) Replication cycle of an NSV (based on a filoviral replication cycle). After entry into the cell (1) and release of the nucleocapsid into the cytoplasm (2), primary viral transcription (3) is initiated by the integrated viral polymerase complex. Viral mRNAs are translated by the host translation machinery (4). Synthesized viral proteins support new rounds of viral transcription (5), replication (6) and nucleocapsid assembly (7). Nucleocapsids are transported (8) to the cell periphery where they assemble to virions (9) and bud from the plasma membrane (10).

The RNA is tightly encapsidated in a non-covalently manner by the nucleoprotein $(\mathrm{N}$, $\mathrm{NP})$ that forms together with the other viral nucleocapsid or accessory proteins a helical Ribonucleoprotein complex (RNP) [61,66-71]. NSV are enveloped viruses that integrate their surface protein $(\mathrm{s})(\mathrm{G}, \mathrm{GP}$, Hemagglutinin $\mathrm{H}$, or fusion protein $\mathrm{F})$ into the host-derived membrane (Figure 2A). A layer of viral matrix protein(s) (M, VP40) represents the matrix that connects the membrane with the nucleocapsid. The replication cycle of nsNSV takes place in the cytoplasm of the host cell, with the exception of Bornaviruses that have a nuclear phase during their replication [72]. Entry of the virus is mediated by the attachment and binding of the surface protein to its receptor and fusion of the viral with the cellular membrane [73-75] (Figure 2C). Subsequently, the viral RNP is released into the cytoplasm of the cell. The RNP serves as template for viral RNA synthesis that starts (owing to the negative-sense genomic RNA) with primary viral transcription accomplished by the incorporated viral polymerase complex [76,77]. The RNA-dependent RNA polymerase (RdRp) L forms together with the phosphoprotein (P, VP35) the viral polymerase complex that enables mRNA synthesis of the viral genes [78,79]. Some representatives of the nsNSV encode additional viral nucleocapsid or accessory proteins that are essential viral transcription factors often regulated by phosphorylation (for example, VP30 for filoviruses or M2-1 for RSV) $[77,80,81]$. mRNA synthesis starts at the $3^{\prime}$-end of the genomic RNA and results in short, uncapped leader RNAs and $5^{\prime}$-capped, $3^{\prime}$-polyadenylated mRNAs $[82,83]$. Transcription of the monocistronic mRNAs is assumed to follow a start-stop mechanism regulated by highly conserved gene start and gene end sequences located in UTRs $[78,84]$. Polyadenylation of the viral mRNAs by the viral polymerase slows down transcription at the gene ends that may result in dissociation of the RdRp from the template. The result is 
a descending gradient of viral mRNAs from the first $(\mathrm{N})$ to the last $(\mathrm{L})$ gene, suggesting that the RdRp initiates transcription predominantly at the $3^{\prime}$-end of the viral genome and not from internal genes $[76,82,85-89]$. Following transcription, the cellular translation machinery translates the mRNAs into new viral proteins. Replication is carried out via the synthesis of a full-length antigenome in positive orientation that serves as a template for replication of the negative-sense genomic RNA. The switch from viral transcription to viral replication, when the RdRp ignores the transcription start and stop signals to synthesize the full-length antigenome, is not completely understood. It is suggested that the amount of newly synthesized $\mathrm{N}$ plays an important role to enable encapsidation of the nascent full-length antigenomic RNA during viral replication. $\mathrm{N}$ is synthesized as a monomer but starts to oligomerize quite rapidly and forms nucleocapsid-like structures, also with cellular RNA [90-92]. To prevent encapsidation of cellular RNA by N, N is kept soluble by the interaction with $\mathrm{P}$ [93]. The $\mathrm{N}^{0} \mathrm{P}$ complex, allows a concerted and regulated encapsidation of the viral RNA template [94]. However, different pools of polymerase complexes complemented by cellular and/or viral co-factors are also discussed to define either transcriptase or replicase activity of the RdRp [95]. Simultaneously with viral replication, genomic RNA serves again as template for further rounds of viral transcription accomplished by the newly synthesized polymerase complex components (secondary transcription).

Encapsidated genomic full-length RNA assembles together with the other nucleocapsid proteins to mature nucleocapsids that are condensed and transported along the cytoskeleton to the sites of viral budding at the cell periphery. The surface protein $G$ co-localizes at the budding sites with the matrix protein $\mathrm{M}$ that drives the incorporation of the nucleocapsids into virions that are subsequently released from the plasma membrane [96-98].

\subsection{Characteristics of Viral Inclusion Bodies (IBs)}

New insights into the attributes of biomolecular condensate formation have also led to a reconsideration of viral IB formation in the virology field. High similarities of viral IB formation with biomolecular condensates driven by LLPS are obvious. Many viral IBs upon infection with nsNSVs have a high dynamic plasticity, they assemble/dissemble rapidly during infection, grow in size and appearance, and allow transport of exclusive molecules from in- or outwards. A major driving force in NSV IB formation is the expression of N and P proteins that are suggested as the basic scaffold in IB formation during infection. Two types of N-P interactions involving different interaction domains have been described: A monomeric $\mathrm{N}^{0} \mathrm{P}$ complex preventing association of $\mathrm{N}$ with cellular $\mathrm{RNA}$, and nucleocapsid-associated $\mathrm{P}$ upon $\mathrm{N}$ oligomerization following its binding to genomic and antigenomic RNA [99]. All these steps involve multiple protein:protein and protein:RNA interactions that are mediated by highly conserved IDRs in both oligomeric proteins, $\mathrm{P}$ and $\mathrm{N}$. All these attributes would contribute to the multivalent interactions underlying LLPS. Furthermore, several studies have demonstrated that de novo RNA synthesis occurs in viral IBs [100-105]. While the cellular protein synthesis itself is often shut down due to the viral infection, viral protein synthesis starts on a large scale. Simultaneously with an excess of viral protein expression, the viral RNA is subsequently replicated, encapsidated by the nucleoprotein and packaged with the nucleocapsid proteins.

All these different steps lead inevitably to strong changes in viral protein:protein interactions or protein:RNA interfaces, that might also contribute to LLPS in the viral IB and its surrounding. Understanding the biophysical mechanisms of viral IB biogenesis and regulation will also contribute to understanding the role and function of IBs for viral multiplication.

\section{Viral Inclusions Formed upon Infection with Non-Segmented Negative Strand RNA Viruses (nsNSV)}

IB formation and changes in the phase separation due to viral infections might lead to the induction of essential subsequent steps of the viral life cycle like, viral RNA synthesis, encapsidation, assembly of nucleocapsid, and their transport to the cellular periphery. In the last years, there is significant new information about the replication of individual 
nsNSV in correlation with LLPS, which we will review in greater detail (summarized in Figure 3).

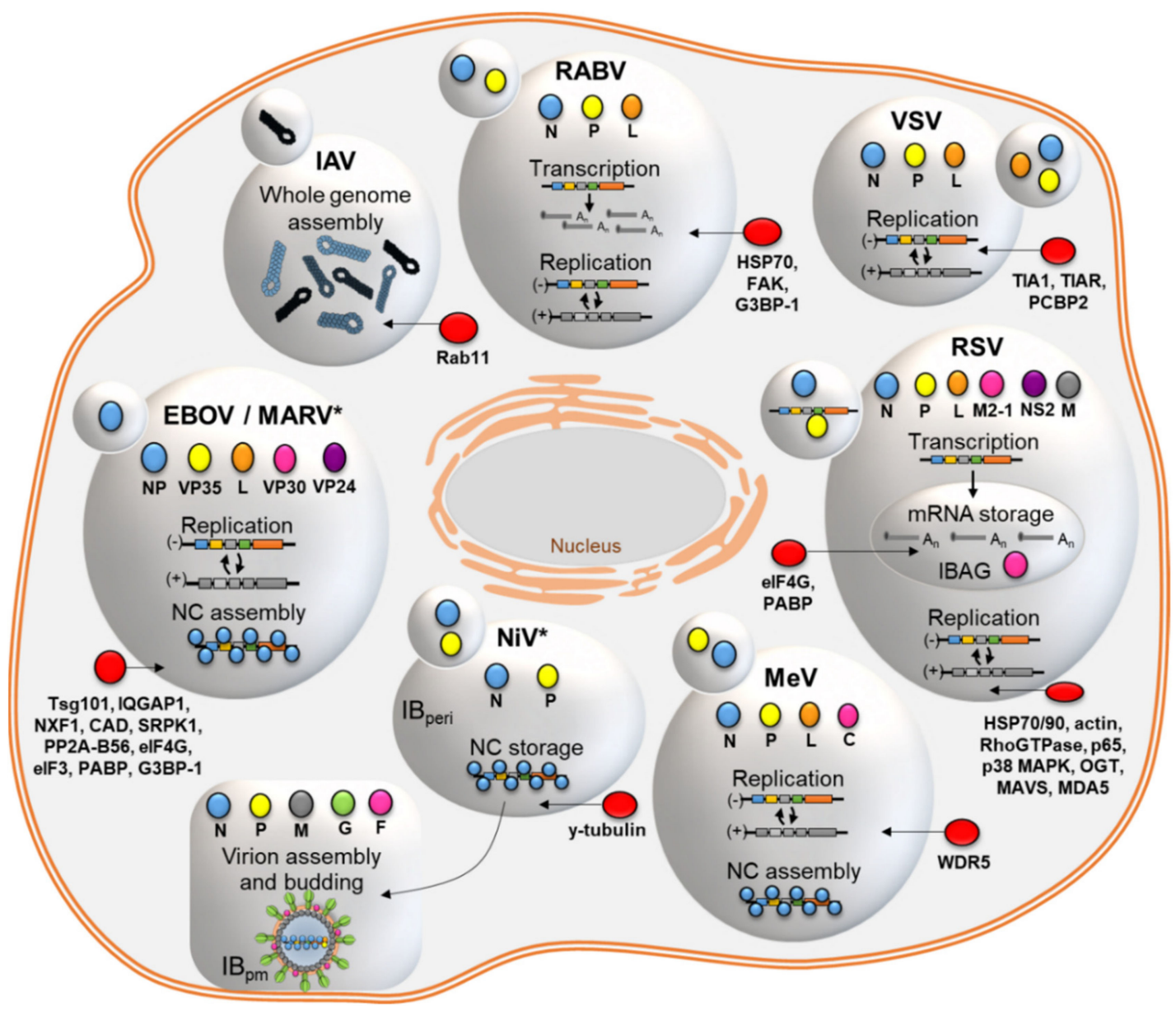

Figure 3. Summary of inclusion body (IB) formation upon infection with NSV. Small IBs indicate minimal required viral proteins for IB formation, while larger IBs represent mature IBs as biomolecular condensates formed by LLPS. * IB formation by LLPS suspected. Different steps of the viral life cycle taking place in IBs as indicated. In red cellular proteins that localize to IBs. RABV, Rabies virus [106]. VSV, vesicular stomatitis virus [103,107]. RSV, Respiratory syncytial virus [101,108]. MeV, Measles virus [109,110]. NiV, Nipah virus [111]. EBOV, Ebola virus [104,105]. MARV, Marburg virus [112,113]. IAV, Influenza A virus [114,115]. IBAG, IB associated granules. IBperi, perinuclear IB. IBpm, IB plasma membrane. NC, nucleocapsid. HSP70/90, heat shock protein 70/90. FAK, focal adhesion kinase. G3BP, Ras GTPase-activating protein-binding protein 1. TIA1, T-cell restricted intracellular antigen 1. TIAR, TIA1-related protein. PCBP2, Poly(RC) Binding Protein 2. p65, NF- $\mathrm{B}$ subunit p65. p65 MAPK, p38 mitogen-activated protein kinase. OGT, O-linked N-acetylglucosamine transferase. MAVS, mitochondrial antiviral-signaling protein. MDA5, melanoma differentiation-associated protein 5. WDR5, WD repeat protein 5. Tsg101, tumor susceptibility gene 101. IQGAP1, Ras GTPase-activating-like protein 1. NXF1, Nuclear RNA export factor 1. CAD, carbamoyl-phosphate synthetase 2, aspar-tate transcarbamylase, and dihydroorotase. SRPK1, Serine-arginine protein kinase. PP2A-B56, protein phosphatase 2 B56 subunit. eIF4G, Eukaryotic translation initiation factor 4 G. eIF3, Eukaryotic initiation factor 3. PABP, Poly(A)-binding protein. Rab11, Ras-related protein Rab-11.

\subsection{Rhabdoviridae: IBs of RABV and VSV}

A prototype of IB formation upon infection with nsNSV are the Negri bodies that are formed in neurons upon infection with RABV [116]. These cytoplasmic IBs were named after their discoverer Aldechi Negri in 1903 and present a hallmark of rabies diagnosis in the central nervous system (CNS). Negri bodies have been described as places of viral transcription and replication [102]. Components of the viral replication machinery are hence localized in Negri bodies as well as the matrix protein M. Apart from that, cellular 
proteins like HSP70 and focal adhesion kinase (FAK) are recruited to those IBs [117-119]. Negri bodies were the first viral IBs that have been demonstrated to present organelles with liquid properties [106]. Using fluorescently labelled RABV together with live-cell imaging and FRAP (fluorescence recovery after photobleaching) technologies, the nature of Negri bodies as biomolecular condensates formed by LLPS was demonstrated. Negri bodies are spherical structures with fusion capacity; they show transit with vesicles and can be in reversible form once they encounter a physical barrier $[106,116]$. The highly dynamic formation of Negri bodies was shown by applying a hypertonic shock to the RABV-infected cells that resulted in the dis- and reappearance of Negri bodies in only $15 \mathrm{~min}$. Interestingly, at later time points of infection, the shape of Negri bodies was changed and they were associated with membranes, most likely derived from the ER $[106,116]$. The minimal requirement for Negri body formation as a biomolecular condensate was the recombinant expression of $\mathrm{N}$ and $\mathrm{P}$ alone. However, the typical pinching off events seen from Negri bodies (most likely RNPs) were missing upon N-P expression, suggesting further viral or cellular factors that contribute to the final nature of Negri bodies. The key domains of $\mathrm{P}$ that mediate Negri body appearance in complex with $\mathrm{N}$ were narrowed down by mutational approaches to the dimerization domain, the amino-terminal part of its second intrinsically disordered domain (IDD2) as well as the C-terminus. IDDs in general have no stable three-dimensional structure, but instead show a high degree in flexibility that can result in binding to other proteins or RNA, as well as in post-translational modifications like phosphorylation [120]. In this regard, IDD1 and IDD2 of P are flanking a dimerization domain (DD) and, like the C-terminus, are phosphorylated. However, phosphorylation of $P$ did not impact Negri body formation [106]. While it was previously shown that stress granules, also liquid organelles, are formed in close proximity to Negri bodies, fusion events or exchange of proteins between both could not be demonstrated, suggesting that both cellular compartments present separate phases within the cytoplasm [106,121].

VSV IBs appear first around $4 \mathrm{~h}$ post infection and are also the major site of VSV RNA synthesis. Primary viral transcription, however, is suggested to take place in the cytoplasm prior to IB formation [103]. VSV IBs were recently shown by live-cell imaging to present liquid organelles, whose formation is dependent on LLPS [107]. Disrupting the microtubule cytoskeleton with nocodazol resulted in round inclusions containing eGFP-P labeled VSV. Those IBs were able to fuse by random motion supporting the hypothesis of intrinsic surface tension of VSV IBs, a characteristic feature of LLPS. In contrast to other members of the nsNSV, besides the expression of P and N, IB formation additionally requires the expression of the VSV polymerase L $[103,107]$. This was tested by recombinant expression of the proteins and complementary by depleting viral protein expression in VSVinfected cells using puromycin, as global protein synthesis inhibitor, or protein-specific PPMOs (peptide-conjugated morpholino oligomers). In addition, the inhibition of $\mathrm{M}$ protein expression using a specific PPMO had no effect on the formation or properties of the IBs [103,107]. Using an inactive mutant of L, L G174A, revealed that IB formation is independent of viral RNA synthesis, suggesting that the nature of the protein:protein interaction is the driving force of VSV IB formation via LLPS.

\subsection{Pneumoviridae: IBs of RSV}

RSV IBs have been described as spherical cytoplasmic structures where viral transcription and replication occurs and to which all viral proteins of polymerase complex, N, P, L, M2-1 are recruited to enable viral RNA synthesis [101,122-124]. Besides the components of the viral polymerase complex, the nonstructural protein NS2 and the matrix protein M are recruited to RSV IBs [125,126]. RSV IBs also recruit cellular proteins involved in translation initiation, like the poly A binding protein PABP, translation initiation factor eIF4G [101], protein phosphatase 1 (for regulating RSV transcription mediated by M2-1 phosphorylation) [81] or heat shock proteins HSP90 and HSP70 [127,128]. Additionally, cellular proteins involved in nucleocapsid assembly and -transport like actin, actin-associated proteins and rhoGTPases like rac1, rhoA and cdc42 colocalize in IBs [129-131]. 
While genomic RNA could be detected in RSV IBs [124,132], a recent study confirmed additionally viral mRNA synthesis to be present in RSV IBs, independent of their size [101]. Live-cell imaging and pulse chase analyses with a fluorescently labelled recombinant RSV (M2-1 GFP fusion protein) underlined the dynamics of IB formation during the RSV replication cycle. A very intriguing finding of this study was the identification of a subcompartment inside the IBs by super-resolution microscopy, called IBAGs (for IBassociated granules), where newly synthesized viral mRNA accumulated together with the viral transcription activator M2-1, while N, P, L, and genomic RNA were excluded [101]. Formation of IBAGs was strongly dependent on viral RNA synthesis as their number increased during the viral replication cycle from $12 \mathrm{~h}$ p.i. on. Interestingly, while nascent viral mRNA and the cellular proteins PABP or eIF4G involved in translation initiation co-localized in IBAGs, other components of the cellular translation machinery, like the ribosomal subunit proteins S6 or L4, did not concentrate on IBs at all. As pulse-chase experiments could demonstrate that newly synthesized viral mRNA only transits through IBAGs, it is suggested that they might present rather transient mRNA storage sites but not sites of viral mRNA translation that most likely occurs in the cytoplasm. IBAGs share similarities with cellular stress granules that are formed by LLPS [133], although IBAGs do not contain typical stress granule proteins like G3BP or TIA-1. The minimal requirement of RSV IB formation is, like for RABV, expression of N and P alone [108,134]. The assembly of IBs was shown to be dependent on the RNA binding- and oligomerization capability of $\mathrm{N}$ and $\mathrm{P}$, as $\mathrm{N}$ mutation towards a $\mathrm{N}^{0} \mathrm{P}$ complex was not sufficient to induce IB assembly in transfected cells [108]. With respect to P, it was demonstrated that the oligomerization domain as well as its C-terminus were essential for IB formation. FRAP experiments on expressed mCherry-tagged $\mathrm{N}$ and $\mathrm{P}$ proteins could demonstrate in cellula as well as in vitro that the formation of RSV IBs occurs by LLPS mediated by N- and P interactions [108].

\subsection{Paramyxoviridae: IBs of $\mathrm{MeV}$ and $\mathrm{NiV}$}

In MeV-infected cells, all the components of the $\mathrm{MeV}$ polymerase complex $\mathrm{N}, \mathrm{P}$, and L, as well as C colocalize in cytoplasmic IBs where also viral RNA synthesis takes place [135-139]. However, IB formation is initiated by the recombinant expression of $\mathrm{N}$ and $\mathrm{P}$ alone, even in the absence of viral replication [109]. Extensive studies during the last years have been made to identify $\mathrm{N}$ and $\mathrm{P}$ domains that contribute to their interaction. Both proteins show a high plasticity with structured and disordered domains. N has been described to consist of a folded domain ( $\left.\mathrm{N}_{\mathrm{CORE}}\right)$ responsible for RNA binding, with two terminal arms followed by a highly flexible region called $\mathrm{N}_{\text {TAIL }}$ [140-143]. The tetrameric $\mathrm{P}$ contains a long intrinsically disordered ( $\left.\mathrm{P}_{\mathrm{TAIL}}\right)$ and a shorter disordered domain $\left(\mathrm{P}_{\mathrm{LOOP}}\right)[140,144,145]$. $\mathrm{P}_{\mathrm{LOOP}}$ is terminated by a small C-terminal three-helix bundle (XD) that has been shown to interact with RNA-associated $\mathrm{N}_{\mathrm{TAIL}}$ and, for parainfluenzavirus 5 also with $\mathrm{L}[144,146]$. In contrast, interaction in the $\mathrm{N}^{0} \mathrm{P}$ complex is mediated via the C-terminal domain of P [147].

Recent studies could demonstrate that $\mathrm{MeV}$ IBs represent biomolecular condensates formed by LLPS [109]. Characteristics of biomolecular condensates and LLPS, like a highly dynamic exchange between materials inside the IB with its surrounding, were observed by live-cell imaging upon $\mathrm{MeV}$ infection. IB formation was highly dynamic from small spherical structures to large inclusions. Interestingly, while smaller IBs were ubiquitously distributed in the cytoplasm, larger IBs appeared at the perinuclear region. By inhibition of dynein, a motor protein, the formation of perinuclear larger IBs was reduced suggesting that small cytoplasmic IBs transported dynein-dependent along microtubules to the cell nucleus to fuse towards larger IBs. Two further important assets of biomolecular condensates could be detected for MeV IB: the recruitment of cellular proteins (for example, eGFP- or mCherrytagged WD-repeat protein (WDR) 5) [138], and recovery from photobleaching [109]. LLPS was initiated by the interaction of the C-terminal disordered region of $\mathrm{N}$ and $\mathrm{P}$. N mutants that were unable to bind RNA could still form N- and P-mediated IBs. This suggests that RNP complexes, an often described driving force for LLPS [35,57-59], do not contribute to 
$\mathrm{MeV}$ IB formation [109], in contrast to RSV [108]. In vitro experiments using co-expressed $\mathrm{N}^{0} \mathrm{P}$ complexes and different mutants thereof confirmed that phase separation in vitro is also mediated by $\mathrm{P}$ and $\mathrm{N}$ interactions [110]. Interestingly interaction of $\mathrm{P}_{\mathrm{XD}}$ and $\mathrm{N}_{\mathrm{TAIL}}$ has been previously described to mediate the transport of the polymerase complex to the nucleocapsid prior to RNA synthesis [144,145,148-150]. Preventing the interaction between $\mathrm{P}$ and $\mathrm{N}$ by an $\mathrm{N}$ S491L mutation, a mutation that reduced viral transcription in cells $[148,151]$, resulted in a complete abrogation of LLPS in vitro. The same was true upon mutation of P S86A and S151A indicating that P phosphorylation also contributes to phase separation. Interestingly, adding RNA to N-P droplets in vitro leads to the recruitment of RNA to droplets and triggered the encapsidation of RNA by $\mathrm{N}$ to nucleocapsid-like structures. The rate of encapsidation in those droplets measured by real-time NMR was enhanced when compared to the dilute phase [110]. These data confirmed the formation of nucleocapsid-like structures in these droplets and suggested a role of LLPS for the maturation of $\mathrm{MeV}$ nucleocapsids.

IB formation is also found upon infection by Mumps virus [152], Parainfluenzavirus 3 [153,154] and 5 [155] and NiV [111] and also initiated mainly by $\mathrm{N}$ and P expression. However, whether those IBs have properties of biomolecular condensates that contribute to efficient viral replication is so far not clear.

$\mathrm{NiV}$, a highly pathogenic member of the Paramyxoviridae, differs from the other nsNSV by the induction of the formation of two distinct types of IB during infection. While one type is localized as spherical structures in the perinuclear region $\left(\mathrm{IB}_{\text {peri }}\right)$, the second type characterized by a square shape is found at the plasma membrane $\left(\mathrm{IB}_{\mathrm{pm}}\right)$ [111]. Both types show not only different localization in the cell but also differ in their kinetics of formation and their content of proteins. While $\mathrm{IB}_{\text {peri }}$ are rapidly formed by $\mathrm{N}$ and $\mathrm{P}$ proteins upon transfection or early in infection, the matrix protein $\mathrm{M}$ is only found inside $\mathrm{IB}_{\mathrm{pm}}$, suggesting that they present places of virion assembly and budding. However, fusion events could not be observed between $\mathrm{IB}_{\mathrm{pm}}$, neither in transfected nor in infected cells suggesting a transport of nucleocapsids through the cell from one IB to another. Another very interesting finding was that $\mathrm{IB}_{\text {peri }}$ did not contain positive-sense RNA (mRNA or antigenomic RNA), suggesting that they represent no places of viral RNA synthesis, which is in contrast to many other nsNSV inclusions bodies. From this study, it is suggested that viral RNA synthesis takes place in a network of membrane-like reticular structures close to the ER [156], which is supported by the detection of nucleocapsids outside the $\mathrm{IB}_{\text {peri }}$. Whether LLPS and phase separation plays a role in the formation of $\mathrm{IB}_{\text {peri }}$ and $\mathrm{IB}_{\mathrm{pm}}$ during $\mathrm{NiV}$ replication is so far not clear.

\subsection{Filoviridae: IBs of $M A R V$ and $E B O V$}

For Filoviruses, it is not clear whether IBs represent virus induced liquid-like compartments characterized by LLPS, as published so far for other NSV [106,107,110]. However, the current literature provides some evidence that this mechanism of compartmentalization, resulting in high functional dynamic and flexibility during the replication cycle, might be applied by filoviruses as well.

Live-cell imaging and time course studies showed that first small IBs appear in the perinuclear region of filovirus-infected cells [104,105] (and own unpublished data for MARV). The small IBs grow with time, they can fuse with each other, and in addition undergo fission events generating smaller IBs from bigger ones [104] (and own unpublished data for MARV). These observations were made using recombinant viruses expressing fluorophore-tagged nucleocapsid proteins like L-mCherry or VP30-GFP and might suggest LLPS processes during IB formation [104,112]. Earlier studies using single protein expression showed that the nucleoprotein NP alone induces the formation of IBs in transfected cells. All other nucleocapsid-associated proteins VP35 (a P analogue), viral nucleocapsid proteins VP30 and VP24, as well as L are diffusely distributed in the cytosol upon single expression and become IBs localized when co-expressed with NP [157-159]. The nucleocapsid proteins are important for the formation and structure of infectious nucleocapsids 
and possess in addition a wide range of functions in the filoviral replication cycle. VP35 is the co-factor of the viral polymerase L and inhibits IFN-signaling [160,161]. VP30 is a phosphorylation-dependent viral transcription factor necessary to initiate the formation of viral mRNAs [77]. VP24 is important for the formation and condensation of nucleocapsids and inhibits viral transcription and replication as well as innate immune response by interfering with interferon-mediated signaling [162-165].

It was recently shown that the $\mathrm{C}$-terminal domain of $\mathrm{EBOV} \mathrm{NP}$ is necessary for IB formation and that co-expression of VP35 can rescue IB formation upon expression of a C-terminal deleted NP [166]. This experiment suggests that IB formation and other functions of NP and VP35 involved in transcription and replication of viral RNA are separated processes, since RNA synthesis could not be rescued in this setting. Functional separation of different protein forms, for example, due to modifications like phosphorylation or different protein:protein complexes can occur by LLPS. Here, MARV and EBOV VP30 phosphorylation represent an example of how this modification changes protein:protein and protein:RNA interactions and influences its functions and localization in IB [77,167-170].

Viral RNA is the second important component detected in filovirus induced IBs [104,105,113]. Since early in infection, when primary transcription of viral mRNA takes place, IBs are not detectable, at later time points when protein translation starts and secondary mRNA transcription is initiated, IB formation colocalizes with de novo RNA synthesis and large IBs coincident with RNA replication [104,105]. Interestingly, IBs with different compositions of viral nucleocapsids proteins like L and VP35 were detected, suggesting the existence of different subsets of IBs with different functional properties [104]. The regulation of transcription and replication in filovirus IBs is still not understood and it has to be worked out if and how LLPS might favor one or the other process by formation of subcompartments, as shown for RSV IBAGs [101].

Ultrastructural analysis using electron microscopy identified IBs in filovirus-infected cells that contained nucleocapsids with different electron-densities [91,162,163,171,172]. Ectopic expression of nucleocapsid proteins revealed that thin-walled helices are formed in the presence of NP [171]. Thick-walled helices with high electron density can only be observed in the presence of NP, VP35, and VP24 [171]. The thick-walled helices are mainly located in the periphery of IBs, at the plasma membrane during viral budding and in extracellular virus particles [171]. It is presumed that the thin-walled helices represent RNPs, which serve as templates for the viral polymerase, and the thick-walled electron dense helices represent mature and transport-competent nucleocapsids in infected cells or nucleocapsid-like structures in transfected cells $[162,171,173]$. Therefore, a proper ratio of NP and VP35 in IBs seems to control the morphogenesis of nucleocapsids in EBOV-infected cells [174].

The formation of transport-competent nucleocapsids that have to be transported from the IBs to the budding sites seems to be highly dependent on VP24 functions in RNP condensation, which in turn blocks EBOV genome replication [162,165,175-177]. Ejection of transport-competent nucleocapsids from MARV and EBOV IBs correlates with high dynamics and the nature of described biomolecular condensates or liquid-like viral factories, which exchange material with the surrounding cytosol, as reviewed by Su and colleagues $[112,178,179]$. In addition, the transport of EBOV and MARV nucleocapsids from IBs to budding sites depends on actin polymerization, and the dynamic of IB assembly and disassembly is dependent on microtubules, representing a further characteristic described for liquid-like viral factories of other NSVs $[104,112,178,180]$.

Filovirus IBs are not membrane-enclosed, as shown in many ultrastructural images; however, often located in close proximity to different cellular membrane compartments like ER, endosomal vesicles, and mitochondria [181-183]. Which and how host cell factors contribute to filovirus IB formation is not known. Several cellular proteins, like Tsg101, IQGAP1, NXF1, CAD and SRPK1, and others have been identified inside IBs, being important for different steps of the filovirus replication cycle [172,177,184-187]. Interestingly, it was published recently that ER contact sites regulate the dynamics of membrane-less organelles like P-bodies [188]. It is therefore also likely that filoviral IBs contact the different cellular 
compartments to enable material exchange, for example, viral and cellular proteins, and RNA, to favor different viral replication steps (transcription and translation, replication, assembly, condensation and transport of nucleocapsids). It remains to be analyzed if the required ATP provided by mitochondria and the necessary translation of viral and cellular proteins in close proximity to IBs might be covered and orchestrated by the mechanisms of liquid-to-solid transitions $[22,189,190]$.

\section{Viral Inclusions Formed upon Infection with Segmented Negative Strand RNA Viruses (sNSV)}

IAV, a member of the Orthomyxoviridae, belongs to the segmented NSVs containing eight segments of RNPs inside the virion. The fact that most virions contain precisely eight segments of each type indicates that genome packaging in IAV infection is a highly regulated process $[171,191,192]$. It is suggested that the whole genome assembly of the eight segments takes place before transport to the plasma membrane, where the final assembly of the virion takes place $[171,193,194]$. In contrast to most other members of the NSVs, IAV replicate their genome in the nucleus. The eight viral RNP segments exit the nucleus and accumulate in IBs in a perinuclear region that enlarge in the course of infection [114,115,195]. Since IAV replication takes place in the nucleus, IBs are no sites of viral RNA synthesis. However, a recent study could demonstrate that IAV IB formation displays characteristics of liquid organelles or biomolecular condensates. Their formation in close proximity of the ER exit sites is spatially regulated, dependent on Rab11-GTPase and shows continuous cycling events of vesicles between the ER and the Golgi apparatus [115,196]. As expression of a single viral RNP could already initiate the formation of viral inclusions, viral IBs obviously occur before the assembly of whole genome RNP complexes. Sharing properties of biomolecular condensates, it is supposed that IAV IBs segregate viral RNPs from the cytosol to increase their concentration at hotspots that, in turn, facilitate the recruitment of other viral RNPs to allow assembly of whole IAV genome complexes [115]. Given the special feature of IAV genome reassortment, it is likely that IAV IB formation plays an important role in the assembly of newly reassorted IAV genomes.

The genus Bunyavirales contains viruses with either bi- or tripartite genomes containing the $\mathrm{L},(\mathrm{M}$,$) and \mathrm{S}$ segments. In contrast to other bunyaviruses, the nonstructural proteins (NSs) of Severe fever with thrombocytopenia syndrome (SFTS) virus were able to form viral IBs upon transfection and infection, whichwas dependent on NSs self-interaction. It could be further demonstrated that those NSs-induced IBs contain the nucleoprotein and are places of viral RNA synthesis [197]. Interestingly, a colocalization of the SFTS IBs with lipid droplets was observed, and inhibition of lipid metabolism negatively affected SFTS replication.

For Bunyamwera virus, viroplasms have been described as tubular structures associated with the Golgi apparatus and the rough ER that are places of viral RNA synthesis and assembly [198]. For Junín virus (an Arenavirus), the nucleoprotein $\mathrm{N}$ was shown to induce the formation of discrete cytosolic IBs that may present viral transcription and replication centers. In contrast to most other nsNSV, those structures were associated with membranes and contained lipid metabolites [199].

However, whether these structures share biochemical properties with biomolecular condensates is so far not clear.

\section{Role of NSV IBs in Antiviral Response}

Given the spatial segregation of viral IB from the surrounding cytoplasm, it is also conceivable that IB formation may function as an additional viral escape strategy to avoid recognition by intracellular components of the antiviral defense machinery. Activation of pattern recognition receptors (PPRs) like RIG-1 and MDA5 recognizing cytosolic dsRNA leads to the activation of type 1 interferon and inflammatory responses combating viral infection [200-202]. A key determinant of antiviral activity are the viral phosphoproteins that are also key regulators for viral IB formation. The P proteins and their analogues have been described to block, for example, phosphorylation of the interferon regulatory 
factor 3 (IRF3) or IRF 7 [203-208], bind to dsRNA, and prevent RIG-I signaling or PKR activation $[207,209,210]$.

Preventing activation of cell-intrinsic defense by IB formation could either be enabled by sterical exclusion or by concentrated sequestration of antiviral sensors avoiding activation of downstream pathways [211].

RSV antagonizes the innate immune response by sequestering cellular proteins involved in antiviral response activities into the IBs, such as NF- $\mathrm{kB}$ subunit $\mathrm{p} 65, \mathrm{p} 38$ mitogenactivated protein kinase (MAPK), O-linked N-acetylglucosamine transferase (OGT), mitochondrial antiviral-signaling protein (MAVS), and MDA5 [132,212,213]. Sequestration of MAPK p38 and OGT was suggested to suppress MK2 activity and formation of stress granules [213]. The cellular proteins were recruited to the IBs most likely via their interaction with $\mathrm{N}$ or $\mathrm{P}$, suggesting an immune evasion strategy independent of the immunomodulatory RSV proteins NS1, NS2, or SH [212]. However, although the NF- $\mathrm{kB}$ subunit p65 was recruited to IBs, there was no co-localization with $\mathrm{N}$ and $\mathrm{P}$ suggesting that p65 localization might be regulated by other multivalent interactions within IBs [212].

Stress granules (SG), also liquid organelles with a role in antiviral activity $[133,214]$ have been found in close proximity to RABV as well as VSV IBs [106,121,215]. While active fusion events between both biomolecular condensates could not be observed for RABV, the SG marker protein G3BP was found in some of the RABV IBs [106]. The function of G3BP localization in RABV IBs is unknown but may point towards the direction that LLPS may exclude antiviral proteins inside viral IBs to block antiviral downstream effectors [106]. For VSV IBs, in contrast, some SG proteins such as T-cell restricted intracellular antigen 1 (TIA1), TIA1-related protein (TIAR) or Poly(RC) Binding Protein 2 (PCBP2) co-localized to IBs [215]. The same is true for the EBOV IFN antagonist VP35 that can disrupt SG formation by sequestration of SG proteins into EBOV IBs (eIF4G, eIF3, PABP, and G3BP-1, but no TIA-1) to block innate immune responses [186,187].

For SFTS virus, a bunyavirus, it was demonstrated that sequestering of antiviral factors like IRF7, RIG-I, or STAT2 into viral IBs via the interaction with NSs leads to the suppression of IFN-alpha and -beta signaling pathways [216-219].

\section{Conclusions}

Over the last decade, the understanding of the intracellular architecture has changed tremendously by the discovery that intracellular membrane-less compartments represent liquid organelles or biomolecular condensates formed by LLPS. This also led to a paradigm change in the field of virology, especially with respect to the underlying mechanism of viral IB formation and maturation. For many NSVs, the liquid properties of IBs could be already demonstrated, with strong evidence that expression of $\mathrm{N}$ and $\mathrm{P}$ proteins are mostly the minimal requirement for IB formation (Figure 3). This could be attributed to their special protein architecture that includes multiple disordered regions and RNA-binding domains, hence multivalent interaction interfaces that contribute to LLPS. While RNA synthesis does take place in some of the NSV IBs, the structural role of RNA synthesis for LLPS formation and contribution to IB maturation is not fully understood, as well as the assembly of viral nucleocapsids in or from matured IBs. One may speculate that the molecular crowding of viral (and also cellular) proteins upon viral infection initiates the formation of IBs above a certain threshold, laying the foundation for the induction of further steps of the viral life cycle, possibly also driven by LLPS. In that regard, nucleocapsid assembly may be triggered as a result of the environmental changes induced by $\mathrm{N}$ and $\mathrm{P}$ expression and RNA synthesis.

Different cellular proteins interacting and co-localizing with viral proteins inside IBs have been identified so far. How they contribute to IB formation and LLPS is until now elusive. It is also feasible that many more cellular proteins might be recruited towards IBs due to their similar physicochemical properties, and maybe not all of them by their direct interaction with a viral protein. These interactions might be transient and require more live cell imaging and time laps studies and the use of super-resolution techniques. Research on 
the composition of IBs in cells will be an exciting field in the future, although challenging, since the liquid properties will make IBs purification difficult. The role of IBs in innate immunity, and how sequestration of cellular antiviral proteins into viral IBs may contribute actively to counteract antiviral activity will be also of great interest in the next years.

Future research on the biogenesis of viral IB formation and the underlying biophysical mechanism will help to understand how IBs promote viral replication, and may lay the foundation of the development of future antivirals, leading to the disassembly of viral IBs or that that may block viral RNA synthesis in place.

Author Contributions: All listed authors (O.D., G.K.G., N.B.) have written, edited, and reviewed the manuscript. G.K.G. provided the visualization. All authors have read and agreed to the published version of the manuscript.

Funding: This work was supported by the Philipps-University Marburg: O.D. (BSL4 facility core staff) and via a junior research group fund from the FCMH (Research Campus of Central Hessen) to N.B. (junior group leader), G.K.G. (post-doctoral position).

Institutional Review Board Statement: Not applicable.

Informed Consent Statement: Not applicable.

Data Availability Statement: Not applicable.

Acknowledgments: In this section, you can acknowledge any support given which is not covered by the author contribution or funding sections. This may include administrative and technical support, or donations in kind (e.g., materials used for experiments).

Conflicts of Interest: The authors declare no conflict of interest.

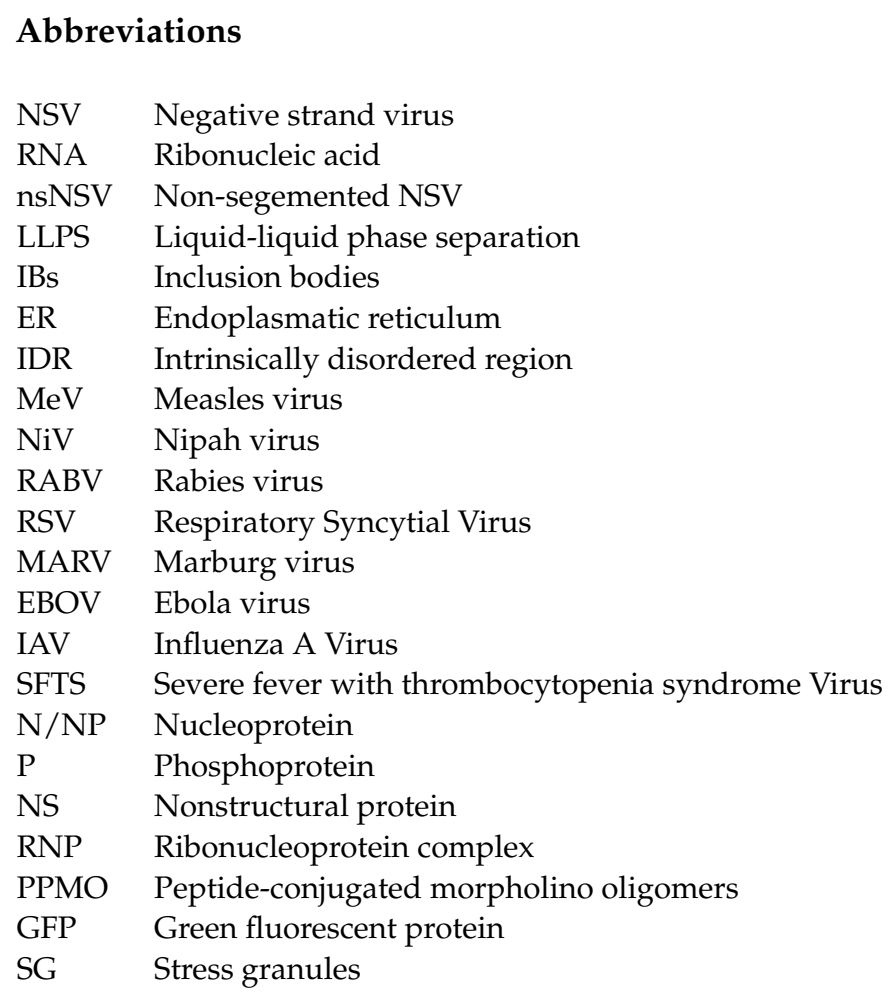

\section{References}

1. Novoa, R.R.; Calderita, G.; Arranz, R.; Fontana, J.; Granzow, H.; Risco, C. Virus factories: Associations of cell organelles for viral replication and morphogenesis. Biol. Cell 2005, 97, 147-172. [CrossRef] [PubMed]

2. Netherton, C.L.; Wileman, T. Virus factories, double membrane vesicles and viroplasm generated in animal cells. Curr. Opin. Virol. 2011, 1, 381-387. [CrossRef] [PubMed] 
3. Romero-Brey, I.; Merz, A.; Chiramel, A.; Lee, J.-Y.; Chlanda, P.; Haselman, U.; Santarella-Mellwig, R.; Habermann, A.; Hoppe, S.; Kallis, S.; et al. Three-dimensional architecture and biogenesis of membrane structures associated with hepatitis $C$ virus replication. PLoS Pathog. 2012, 8, e1003056. [CrossRef] [PubMed]

4. Romero-Brey, I.; Berger, C.; Kallis, S.; Kolovou, A.; Paul, D.; Lohmann, V.; Bartenschlager, R. NS5A Domain 1 and Polyprotein Cleavage Kinetics Are Critical for Induction of Double-Membrane Vesicles Associated with Hepatitis C Virus Replication. mBio 2015, 6, e00759. [CrossRef] [PubMed]

5. Welsch, S.; Miller, S.; Romero-Brey, I.; Merz, A.; Bleck, C.K.E.; Walther, P.; Fuller, S.D.; Antony, C.; Krijnse-Locker, J.; Bartenschlager, R. Composition and three-dimensional architecture of the dengue virus replication and assembly sites. Cell Host Microbe 2009, 5, 365-375. [CrossRef]

6. Klein, S.; Cortese, M.; Winter, S.L.; Wachsmuth-Melm, M.; Neufeldt, C.J.; Cerikan, B.; Stanifer, M.L.; Boulant, S.; Bartenschlager, R.; Chlanda, P. SARS-CoV-2 structure and replication characterized by in situ cryo-electron tomography. Nat. Commun. 2020, 11, 5885. [CrossRef]

7. Snijder, E.J.; Limpens, R.W.A.L.; de Wilde, A.H.; de Jong, A.W.M.; Zevenhoven-Dobbe, J.C.; Maier, H.J.; Faas, F.F.G.A.; Koster, A.J.; Bárcena, M. A unifying structural and functional model of the coronavirus replication organelle: Tracking down RNA synthesis. PLoS Biol. 2020, 18, e3000715. [CrossRef]

8. Spuul, P.; Balistreri, G.; Kääriäinen, L.; Ahola, T. Phosphatidylinositol 3-kinase-, actin-, and microtubule-dependent transport of Semliki Forest Virus replication complexes from the plasma membrane to modified lysosomes. J. Virol. 2010, 84, 7543-7557. [CrossRef]

9. Short, J.R.; Speir, J.A.; Gopal, R.; Pankratz, L.M.; Lanman, J.; Schneemann, A. Role of Mitochondrial Membrane Spherules in Flock House Virus Replication. J. Virol. 2016, 90, 3676-3683. [CrossRef] [PubMed]

10. Wolff, G.; Limpens, R.W.A.L.; Zevenhoven-Dobbe, J.C.; Laugks, U.; Zheng, S.; de Jong, A.W.M.; Koning, R.I.; Agard, D.A.; Grünewald, K.; Koster, A.J.; et al. A molecular pore spans the double membrane of the coronavirus replication organelle. Science 2020, 369, 1395-1398. [CrossRef] [PubMed]

11. Wolff, G.; Melia, C.E.; Snijder, E.J.; Bárcena, M. Double-Membrane Vesicles as Platforms for Viral Replication. Trends Microbiol. 2020, 28, 1022-1033. [CrossRef] [PubMed]

12. Knoops, K.; Kikkert, M.; van den Worm, S.H.E.; Zevenhoven-Dobbe, J.C.; van der Meer, Y.; Koster, A.J.; Mommaas, A.M.; Snijder, E.J. SARS-coronavirus replication is supported by a reticulovesicular network of modified endoplasmic reticulum. PLoS Biol. 2008, 6, e226. [CrossRef] [PubMed]

13. Oudshoorn, D.; Rijs, K.; Limpens, R.W.A.L.; Groen, K.; Koster, A.J.; Snijder, E.J.; Kikkert, M.; Bárcena, M. Expression and Cleavage of Middle East Respiratory Syndrome Coronavirus nsp3-4 Polyprotein Induce the Formation of Double-Membrane Vesicles That Mimic Those Associated with Coronaviral RNA Replication. mBio 2017, 8. [CrossRef]

14. Wong, L.H.; Edgar, J.R.; Martello, A.; Ferguson, B.J.; Eden, E.R. Exploiting Connections for Viral Replication. Front. Cell Dev. Biol. 2021, 9, 640456. [CrossRef]

15. Hernandez-Gonzalez, M.; Larocque, G.; Way, M. Viral use and subversion of membrane organization and trafficking. J. Cell Sci. 2021, 134. [CrossRef] [PubMed]

16. Banani, S.F.; Lee, H.O.; Hyman, A.A.; Rosen, M.K. Biomolecular condensates: Organizers of cellular biochemistry. Nat. Rev. Mol. Cell Biol. 2017, 18, 285-298. [CrossRef]

17. Uversky, V.N. Intrinsically disordered proteins in overcrowded milieu: Membrane-less organelles, phase separation, and intrinsic disorder. Curr. Opin. Struct. Biol. 2017, 44, 18-30. [CrossRef] [PubMed]

18. Hyman, A.A.; Weber, C.A.; Jülicher, F. Liquid-liquid phase separation in biology. Annu. Rev. Cell Dev. Biol. 2014, 30, 39-58. [CrossRef]

19. Alberti, S. Phase separation in biology. Curr. Biol. 2017, 27, R1097-R1102. [CrossRef]

20. Feng, Z.; Chen, X.; Wu, X.; Zhang, M. Formation of biological condensates via phase separation: Characteristics, analytical methods, and physiological implications. J. Biol. Chem. 2019, 294, 14823-14835. [CrossRef] [PubMed]

21. Alberti, S.; Gladfelter, A.; Mittag, T. Considerations and Challenges in Studying Liquid-Liquid Phase Separation and Biomolecular Condensates. Cell 2019, 176, 419-434. [CrossRef]

22. Etibor, T.A.; Yamauchi, Y.; Amorim, M.J. Liquid Biomolecular Condensates and Viral Lifecycles: Review and Perspectives. Viruses 2021, 13. [CrossRef]

23. Brangwynne, C.P.; Eckmann, C.R.; Courson, D.S.; Rybarska, A.; Hoege, C.; Gharakhani, J.; Jülicher, F.; Hyman, A.A. Germline P granules are liquid droplets that localize by controlled dissolution/condensation. Science 2009, 324, 1729-1732. [CrossRef] [PubMed]

24. Boeynaems, S.; Alberti, S.; Fawzi, N.L.; Mittag, T.; Polymenidou, M.; Rousseau, F.; Schymkowitz, J.; Shorter, J.; Wolozin, B.; van den Bosch, L.; et al. Protein Phase Separation: A New Phase in Cell Biology. Trends Cell Biol. 2018, 28, 420-435. [CrossRef]

25. Courchaine, E.M.; Lu, A.; Neugebauer, K.M. Droplet organelles? EMBO J. 2016, 35, 1603-1612. [CrossRef]

26. Tena-Solsona, M.; Wanzke, C.; Riess, B.; Bausch, A.R.; Boekhoven, J. Self-selection of dissipative assemblies driven by primitive chemical reaction networks. Nat. Commun. 2018, 9, 2044. [CrossRef]

27. Gomes, E.; Shorter, J. The molecular language of membraneless organelles. J. Biol. Chem. 2019, 294, 7115-7127. [CrossRef] [PubMed] 
28. Jalihal, A.P.; Pitchiaya, S.; Xiao, L.; Bawa, P.; Jiang, X.; Bedi, K.; Parolia, A.; Cieslik, M.; Ljungman, M.; Chinnaiyan, A.M.; et al. Multivalent Proteins Rapidly and Reversibly Phase-Separate upon Osmotic Cell Volume Change. Mol. Cell 2020, 79, 978-990.e5. [CrossRef] [PubMed]

29. Jalihal, A.P.; Schmidt, A.; Gao, G.; Little, S.; Pitchiaya, S.; Walter, N.G. Hyperosmotic phase separation: Condensates beyond inclusions, granules and organelles. J. Biol. Chem. 2020. [CrossRef] [PubMed]

30. Mitrea, D.M.; Kriwacki, R.W. Phase separation in biology; functional organization of a higher order. Cell Commun. Signal. 2016, 14, 1. [CrossRef] [PubMed]

31. Franzmann, T.M.; Jahnel, M.; Pozniakovsky, A.; Mahamid, J.; Holehouse, A.S.; Nüske, E.; Richter, D.; Baumeister, W.; Grill, S.W.; Pappu, R.V.; et al. Phase separation of a yeast prion protein promotes cellular fitness. Science 2018, 359. [CrossRef]

32. Abbondanzieri, E.A.; Meyer, A.S. More than just a phase: The search for membraneless organelles in the bacterial cytoplasm. Curr. Genet. 2019, 65, 691-694. [CrossRef]

33. Belott, C.; Janis, B.; Menze, M.A. Liquid-liquid phase separation promotes animal desiccation tolerance. Proc. Natl. Acad. Sci. USA 2020, 117, 27676-27684. [CrossRef]

34. Emenecker, R.J.; Holehouse, A.S.; Strader, L.C. Biological Phase Separation and Biomolecular Condensates in Plants. Annu. Rev. Plant Biol. 2021. [CrossRef]

35. Sanders, D.W.; Kedersha, N.; Lee, D.S.W.; Strom, A.R.; Drake, V.; Riback, J.A.; Bracha, D.; Eeftens, J.M.; Iwanicki, A.; Wang, A.; et al. Competing Protein-RNA Interaction Networks Control Multiphase Intracellular Organization. Cell 2020, 181, 306-324.e28. [CrossRef]

36. Anderson, P.; Kedersha, N. RNA granules. J. Cell Biol. 2006, 172, 803-808. [CrossRef] [PubMed]

37. Lin, Y.; Protter, D.S.W.; Rosen, M.K.; Parker, R. Formation and Maturation of Phase-Separated Liquid Droplets by RNA-Binding Proteins. Mol. Cell 2015, 60, 208-219. [CrossRef]

38. Jin, M.; Fuller, G.G.; Han, T.; Yao, Y.; Alessi, A.F.; Freeberg, M.A.; Roach, N.P.; Moresco, J.J.; Karnovsky, A.; Baba, M.; et al. Glycolytic Enzymes Coalesce in G Bodies under Hypoxic Stress. Cell Rep. 2017, 20, 895-908. [CrossRef] [PubMed]

39. Brangwynne, C.P.; Mitchison, T.J.; Hyman, A.A. Active liquid-like behavior of nucleoli determines their size and shape in Xenopus laevis oocytes. Proc. Natl. Acad. Sci. USA 2011, 108, 4334-4339. [CrossRef] [PubMed]

40. Handwerger, K.E.; Gall, J.G. Subnuclear organelles: New insights into form and function. Trends Cell Biol. 2006, 16, 19-26. [CrossRef] [PubMed]

41. Feric, M.; Vaidya, N.; Harmon, T.S.; Mitrea, D.M.; Zhu, L.; Richardson, T.M.; Kriwacki, R.W.; Pappu, R.V.; Brangwynne, C.P. Coexisting Liquid Phases Underlie Nucleolar Subcompartments. Cell 2016, 165, 1686-1697. [CrossRef]

42. Sawyer, I.A.; Sturgill, D.; Dundr, M. Membraneless nuclear organelles and the search for phases within phases. Wiley Interdiscip. Rev. RNA 2019, 10, e1514. [CrossRef]

43. Hyman, A.A.; Simons, K. Cell biology. Beyond oil and water-phase transitions in cells. Science 2012, 337, 1047-1049. [CrossRef]

44. Dignon, G.L.; Best, R.B.; Mittal, J. Biomolecular Phase Separation: From Molecular Driving Forces to Macroscopic Properties. Annu. Rev. Phys. Chem. 2020, 71, 53-75. [CrossRef]

45. Dignon, G.L.; Zheng, W.; Kim, Y.C.; Mittal, J. Temperature-Controlled Liquid-Liquid Phase Separation of Disordered Proteins. ACS Cent. Sci. 2019, 5, 821-830. [CrossRef] [PubMed]

46. Dignon, G.L.; Zheng, W.; Mittal, J. Simulation methods for liquid-liquid phase separation of disordered proteins. Curr. Opin. Chem. Eng. 2019, 23, 92-98. [CrossRef]

47. Wang, J.; Choi, J.-M.; Holehouse, A.S.; Lee, H.O.; Zhang, X.; Jahnel, M.; Maharana, S.; Lemaitre, R.; Pozniakovsky, A.; Drechsel, D.; et al. A Molecular Grammar Governing the Driving Forces for Phase Separation of Prion-like RNA Binding Proteins. Cell 2018, 174, 688-699.e16. [CrossRef]

48. Thandapani, P.; O'Connor, T.R.; Bailey, T.L.; Richard, S. Defining the RGG/RG motif. Mol. Cell 2013, 50, 613-623. [CrossRef] [PubMed]

49. Lin, Y.-H.; Forman-Kay, J.D.; Chan, H.S. Theories for Sequence-Dependent Phase Behaviors of Biomolecular Condensates. Biochemistry 2018, 57, 2499-2508. [CrossRef]

50. Posey, A.E.; Holehouse, A.S.; Pappu, R.V. Phase Separation of Intrinsically Disordered Proteins. Methods Enzymol. 2018, 611, 1-30. [CrossRef] [PubMed]

51. Protter, D.S.W.; Rao, B.S.; van Treeck, B.; Lin, Y.; Mizoue, L.; Rosen, M.K.; Parker, R. Intrinsically Disordered Regions Can Contribute Promiscuous Interactions to RNP Granule Assembly. Cell Rep. 2018, 22, 1401-1412. [CrossRef]

52. Zhou, H.-X.; Nguemaha, V.; Mazarakos, K.; Qin, S. Why Do Disordered and Structured Proteins Behave Differently in Phase Separation? Trends Biochem. Sci. 2018, 43, 499-516. [CrossRef]

53. Rai, A.K.; Chen, J.-X.; Selbach, M.; Pelkmans, L. Kinase-controlled phase transition of membraneless organelles in mitosis. Nature 2018, 559, 211-216. [CrossRef]

54. Bah, A.; Forman-Kay, J.D. Modulation of Intrinsically Disordered Protein Function by Post-translational Modifications. J. Biol. Chem. 2016, 291, 6696-6705. [CrossRef] [PubMed]

55. Owen, I.; Shewmaker, F. The Role of Post-Translational Modifications in the Phase Transitions of Intrinsically Disordered Proteins. Int. J. Mol. Sci. 2019, 20, 5501. [CrossRef] [PubMed]

56. Hofweber, M.; Dormann, D. Friend or foe-Post-translational modifications as regulators of phase separation and RNP granule dynamics. J. Biol. Chem. 2019, 294, 7137-7150. [CrossRef] [PubMed] 
57. Banerjee, P.R.; Milin, A.N.; Moosa, M.M.; Onuchic, P.L.; Deniz, A.A. Reentrant Phase Transition Drives Dynamic Substructure Formation in Ribonucleoprotein Droplets. Angew. Chem. Int. Ed Engl. 2017, 56, 11354-11359. [CrossRef] [PubMed]

58. Maharana, S.; Wang, J.; Papadopoulos, D.K.; Richter, D.; Pozniakovsky, A.; Poser, I.; Bickle, M.; Rizk, S.; Guillén-Boixet, J.; Franzmann, T.M.; et al. RNA buffers the phase separation behavior of prion-like RNA binding proteins. Science 2018, 360, 918-921. [CrossRef]

59. Berry, J.; Weber, S.C.; Vaidya, N.; Haataja, M.; Brangwynne, C.P. RNA transcription modulates phase transition-driven nuclear body assembly. Proc. Natl. Acad. Sci. USA 2015, 112, E5237-E5245. [CrossRef]

60. Amarasinghe, G.K.; Ayllón, M.A.; Bào, Y.; Basler, C.F.; Bavari, S.; Blasdell, K.R.; Briese, T.; Brown, P.A.; Bukreyev, A.; BalkemaBuschmann, A.; et al. Taxonomy of the order Mononegavirales: Update 2019. Arch. Virol. 2019, 164, 1967-1980. [CrossRef]

61. Lamb, R.A. Mononegavirales. Fields Virol. 2013, 1, 880-884.

62. Le Mercier, P.; Kolakofsky, D. Bipartite promoters and RNA editing of paramyxoviruses and filoviruses. RNA 2019, 25, 279-285. [CrossRef] [PubMed]

63. Whelan, S.P.; Wertz, G.W. Regulation of RNA synthesis by the genomic termini of vesicular stomatitis virus: Identification of distinct sequences essential for transcription but not replication. J. Virol. 1999, 73, 297-306. [CrossRef] [PubMed]

64. Pong, L.Y.; Rabu, A.; Ibrahim, N. The critical region for viral RNA encapsidation in leader promoter of Nipah virus. Mol. Genet. Genom. 2020, 295, 1501-1516. [CrossRef]

65. Bach, S.; Demper, J.-C.; Biedenkopf, N.; Becker, S.; Hartmann, R.K. RNA secondary structure at the transcription start site influences EBOV transcription initiation and replication in a length- and stability-dependent manner. RNA Biol. 2021, 18, 523-536. [CrossRef]

66. Luo, M.; Terrell, J.R.; Mcmanus, S.A. Nucleocapsid Structure of Negative Strand RNA Virus. Viruses 2020, 12, 835. [CrossRef]

67. Wan, W.; Kolesnikova, L.; Clarke, M.; Koehler, A.; Noda, T.; Becker, S.; Briggs, J.A.G. Structure and assembly of the Ebola virus nucleocapsid. Nature 2017, 551, 394-397. [CrossRef]

68. Green, T.J.; Zhang, X.; Wertz, G.W.; Luo, M. Structure of the vesicular stomatitis virus nucleoprotein-RNA complex. Science 2006, 313, 357-360. [CrossRef]

69. Albertini, A.A.V.; Wernimont, A.K.; Muziol, T.; Ravelli, R.B.G.; Clapier, C.R.; Schoehn, G.; Weissenhorn, W.; Ruigrok, R.W.H Crystal structure of the rabies virus nucleoprotein-RNA complex. Science 2006, 313, 360-363. [CrossRef]

70. Sugita, Y.; Matsunami, H.; Kawaoka, Y.; Noda, T.; Wolf, M. Cryo-EM structure of the Ebola virus nucleoprotein-RNA complex at 3.6 Åresolution. Nature 2018, 563, 137-140. [CrossRef]

71. Tawar, R.G.; Duquerroy, S.; Vonrhein, C.; Varela, P.F.; Damier-Piolle, L.; Castagné, N.; MacLellan, K.; Bedouelle, H.; Bricogne, G.; Bhella, D.; et al. Crystal structure of a nucleocapsid-like nucleoprotein-RNA complex of respiratory syncytial virus. Science 2009, 326, 1279-1283. [CrossRef]

72. Tomonaga, K.; Kobayashi, T.; Ikuta, K. Molecular and cellular biology of Borna disease virus infection. Microbes Infect. 2002, 4, 491-500. [CrossRef]

73. Guo, Y.; Duan, M.; Wang, X.; Gao, J.; Guan, Z.; Zhang, M. Early events in rabies virus infection-Attachment, entry, and intracellular trafficking. Virus Res. 2019, 263, 217-225. [CrossRef]

74. Fukuhara, H.; Mwaba, M.H.; Maenaka, K. Structural characteristics of measles virus entry. Curr. Opin. Virol. 2020, 41, 52-58. [CrossRef]

75. Aggarwal, M.; Plemper, R.K. Structural Insight into Paramyxovirus and Pneumovirus Entry Inhibition. Viruses 2020, $12,342$. [CrossRef] [PubMed]

76. Noton, S.L.; Fearns, R. Initiation and regulation of paramyxovirus transcription and replication. Virology 2015, 479-480, 545-554. [CrossRef] [PubMed]

77. Biedenkopf, N.; Lier, C.; Becker, S. Dynamic Phosphorylation of VP30 Is Essential for Ebola Virus Life Cycle. J. Virol. 2016, 90, 4914-4925. [CrossRef] [PubMed]

78. Cao, D.; Gao, Y.; Liang, B. Structural Insights into the Respiratory Syncytial Virus RNA Synthesis Complexes. Viruses 2021, 13, 834. [CrossRef] [PubMed]

79. Fearns, R.; Plemper, R.K. Polymerases of paramyxoviruses and pneumoviruses. Virus Res. 2017, 234, 87-102. [CrossRef] [PubMed]

80. Weik, M.; Modrof, J.; Klenk, H.-D.; Becker, S.; Mühlberger, E. Ebola virus VP30-mediated transcription is regulated by RNA secondary structure formation. J. Virol. 2002, 76, 8532-8539. [CrossRef]

81. Richard, C.-A.; Rincheval, V.; Lassoued, S.; Fix, J.; Cardone, C.; Esneau, C.; Nekhai, S.; Galloux, M.; Rameix-Welti, M.-A.; Sizun, C.; et al. RSV hijacks cellular protein phosphatase 1 to regulate M2-1 phosphorylation and viral transcription. PLoS Pathog. 2018, 14, e1006920. [CrossRef]

82. Ogino, T.; Green, T.J. RNA Synthesis and Capping by Non-segmented Negative Strand RNA Viral Polymerases: Lessons From a Prototypic Virus. Front. Microbiol. 2019, 10, 1490. [CrossRef]

83. Ogino, T.; Green, T.J. Transcriptional Control and mRNA Capping by the GDP Polyribonucleotidyltransferase Domain of the Rabies Virus Large Protein. Viruses 2019, 11, 504. [CrossRef]

84. Whelan, S.P.J.; Barr, J.N.; Wertz, G.W. Transcription and replication of nonsegmented negative-strand RNA viruses. Curr. Top. Microbiol. Immunol. 2004, 283, 61-119. [CrossRef] [PubMed]

85. Cordey, S.; Roux, L. Transcribing paramyxovirus RNA polymerase engages the template at its $3^{\prime}$ extremity. J. Gen. Virol. 2006, 87, 665-672. [CrossRef] 
86. Mühlberger, E. Filovirus replication and transcription. Future Virol. 2007, 2, 205-215. [CrossRef] [PubMed]

87. Albariño, C.G.; Wiggleton Guerrero, L.; Chakrabarti, A.K.; Nichol, S.T. Transcriptional analysis of viral mRNAs reveals common transcription patterns in cells infected by five different filoviruses. PLoS ONE 2018, 13, e0201827. [CrossRef]

88. Shabman, R.S.; Jabado, O.J.; Mire, C.E.; Stockwell, T.B.; Edwards, M.; Mahajan, M.; Geisbert, T.W.; Basler, C.F. Deep sequencing identifies noncanonical editing of Ebola and Marburg virus RNAs in infected cells. mBio 2014, 5, e02011. [CrossRef]

89. Cowton, V.M.; McGivern, D.R.; Fearns, R. Unravelling the complexities of respiratory syncytial virus RNA synthesis. J. Gen. Virol. 2006, 87, 1805-1821. [CrossRef]

90. Noda, T.; Hagiwara, K.; Sagara, H.; Kawaoka, Y. Characterization of the Ebola virus nucleoprotein-RNA complex. J. Gen. Virol. 2010, 91, 1478-1483. [CrossRef] [PubMed]

91. Kolesnikova, L.; Mühlberger, E.; Ryabchikova, E.; Becker, S. Ultrastructural organization of recombinant Marburg virus nucleoprotein: Comparison with Marburg virus inclusions. J. Virol. 2000, 74, 3899-3904. [CrossRef]

92. Watanabe, S.; Noda, T.; Kawaoka, Y. Functional mapping of the nucleoprotein of Ebola virus. J. Virol. 2006, 80, 3743-3751. [CrossRef] [PubMed]

93. Liu, B.; Dong, S.; Li, G.; Wang, W.; Liu, X.; Wang, Y.; Yang, C.; Rao, Z.; Guo, Y. Structural Insight into Nucleoprotein Conformation Change Chaperoned by VP35 Peptide in Marburg Virus. J. Virol. 2017, 91. [CrossRef] [PubMed]

94. Renner, M.; Bertinelli, M.; Leyrat, C.; Paesen, G.C.; de Oliveira, L.F.S.; Huiskonen, J.T.; Grimes, J.M. Nucleocapsid assembly in pneumoviruses is regulated by conformational switching of the N protein. Elife 2016, 5, e12627. [CrossRef]

95. Qanungo, K.R.; Shaji, D.; Mathur, M.; Banerjee, A.K. Two RNA polymerase complexes from vesicular stomatitis virus-infected cells that carry out transcription and replication of genome RNA. Proc. Natl. Acad. Sci. USA 2004, 101, 5952-5957. [CrossRef] [PubMed]

96. Gordon, T.B.; Hayward, J.A.; Marsh, G.A.; Baker, M.L.; Tachedjian, G. Host and Viral Proteins Modulating Ebola and Marburg Virus Egress. Viruses 2019, 11, 25. [CrossRef]

97. El Najjar, F.; Schmitt, A.P.; Dutch, R.E. Paramyxovirus glycoprotein incorporation, assembly and budding: A three way dance for infectious particle production. Viruses 2014, 6, 3019-3054. [CrossRef] [PubMed]

98. Cox, R.M.; Plemper, R.K. Structure and organization of paramyxovirus particles. Curr. Opin. Virol. 2017, 24, 105-114. [CrossRef] [PubMed]

99. Ruigrok, R.W.H.; Crépin, T.; Kolakofsky, D. Nucleoproteins and nucleocapsids of negative-strand RNA viruses. Curr. Opin. Microbiol. 2011, 14, 504-510. [CrossRef]

100. Cifuentes-Muñoz, N.; Branttie, J.; Slaughter, K.B.; Dutch, R.E. Human Metapneumovirus Induces Formation of Inclusion Bodies for Efficient Genome Replication and Transcription. J. Virol. 2017, 91. [CrossRef] [PubMed]

101. Rincheval, V.; Lelek, M.; Gault, E.; Bouillier, C.; Sitterlin, D.; Blouquit-Laye, S.; Galloux, M.; Zimmer, C.; Eleouet, J.-F.; RameixWelti, M.-A. Functional organization of cytoplasmic inclusion bodies in cells infected by respiratory syncytial virus. Nat. Commun. 2017, 8, 563. [CrossRef]

102. Lahaye, X.; Vidy, A.; Pomier, C.; Obiang, L.; Harper, F.; Gaudin, Y.; Blondel, D. Functional characterization of Negri bodies (NBs) in rabies virus-infected cells: Evidence that NBs are sites of viral transcription and replication. J. Virol. 2009, 83, 7948-7958. [CrossRef] [PubMed]

103. Heinrich, B.S.; Cureton, D.K.; Rahmeh, A.A.; Whelan, S.P.J. Protein expression redirects vesicular stomatitis virus RNA synthesis to cytoplasmic inclusions. PLoS Pathog. 2010, 6, e1000958. [CrossRef] [PubMed]

104. Hoenen, T.; Shabman, R.S.; Groseth, A.; Herwig, A.; Weber, M.; Schudt, G.; Dolnik, O.; Basler, C.F.; Becker, S.; Feldmann, H. Inclusion bodies are a site of ebolavirus replication. J. Virol. 2012, 86, 11779-11788. [CrossRef]

105. Nanbo, A.; Watanabe, S.; Halfmann, P.; Kawaoka, Y. The spatio-temporal distribution dynamics of Ebola virus proteins and RNA in infected cells. Sci. Rep. 2013, 3, 1206. [CrossRef]

106. Nikolic, J.; Le Bars, R.; Lama, Z.; Scrima, N.; Lagaudrière-Gesbert, C.; Gaudin, Y.; Blondel, D. Negri bodies are viral factories with properties of liquid organelles. Nat. Commun. 2017, 8, 58. [CrossRef] [PubMed]

107. Heinrich, B.S.; Maliga, Z.; Stein, D.A.; Hyman, A.A.; Whelan, S.P.J. Phase Transitions Drive the Formation of Vesicular Stomatitis Virus Replication Compartments. mBio 2018, 9. [CrossRef] [PubMed]

108. Galloux, M.; Risso-Ballester, J.; Richard, C.-A.; Fix, J.; Rameix-Welti, M.-A.; Eléouët, J.-F. Minimal Elements Required for the Formation of Respiratory Syncytial Virus Cytoplasmic Inclusion Bodies In Vivo and In Vitro. mBio 2020, 11. [CrossRef] [PubMed]

109. Zhou, Y.; Su, J.M.; Samuel, C.E.; Ma, D. Measles Virus Forms Inclusion Bodies with Properties of Liquid Organelles. J. Virol. 2019, 93. [CrossRef]

110. Guseva, S.; Milles, S.; Jensen, M.R.; Salvi, N.; Kleman, J.-P.; Maurin, D.; Ruigrok, R.W.H.; Blackledge, M. Measles virus nucleoand phosphoproteins form liquid-like phase-separated compartments that promote nucleocapsid assembly. Sci. Adv. 2020, 6, eaaz7095. [CrossRef]

111. Ringel, M.; Heiner, A.; Behner, L.; Halwe, S.; Sauerhering, L.; Becker, N.; Dietzel, E.; Sawatsky, B.; Kolesnikova, L.; Maisner, A. Nipah virus induces two inclusion body populations: Identification of novel inclusions at the plasma membrane. PLoS Pathog. 2019, 15, e1007733. [CrossRef] [PubMed]

112. Schudt, G.; Kolesnikova, L.; Dolnik, O.; Sodeik, B.; Becker, S. Live-cell imaging of Marburg virus-infected cells uncovers actindependent transport of nucleocapsids over long distances. Proc. Natl. Acad. Sci. USA 2013, 110, 14402-14407. [CrossRef] [PubMed] 
113. Dolnik, O.; Stevermann, L.; Kolesnikova, L.; Becker, S. Marburg virus inclusions: A virus-induced microcompartment and interface to multivesicular bodies and the late endosomal compartment. Eur. J. Cell Biol. 2015, 94, 323-331. [CrossRef] [PubMed]

114. Chou, Y.; Heaton, N.S.; Gao, Q.; Palese, P.; Singer, R.H.; Singer, R.; Lionnet, T. Colocalization of different influenza viral RNA segments in the cytoplasm before viral budding as shown by single-molecule sensitivity FISH analysis. PLoS Pathog. 2013, 9, e1003358. [CrossRef]

115. Alenquer, M.; Vale-Costa, S.; Etibor, T.A.; Ferreira, F.; Sousa, A.L.; Amorim, M.J. Influenza A virus ribonucleoproteins form liquid organelles at endoplasmic reticulum exit sites. Nat. Commun. 2019, 10, 1629. [CrossRef]

116. Nikolic, J.; Lagaudrière-Gesbert, C.; Scrima, N.; Blondel, D.; Gaudin, Y. Structure and Function of Negri Bodies. Adv. Exp. Med. Biol. 2019, 1215, 111-127. [CrossRef] [PubMed]

117. Pollin, R.; Granzow, H.; Köllner, B.; Conzelmann, K.-K.; Finke, S. Membrane and inclusion body targeting of lyssavirus matrix proteins. Cell. Microbiol. 2013, 15, 200-212. [CrossRef]

118. Lahaye, X.; Vidy, A.; Fouquet, B.; Blondel, D. Hsp70 protein positively regulates rabies virus infection. J. Virol. 2012, 86, 4743-4751. [CrossRef]

119. Fouquet, B.; Nikolic, J.; Larrous, F.; Bourhy, H.; Wirblich, C.; Lagaudrière-Gesbert, C.; Blondel, D. Focal adhesion kinase is involved in rabies virus infection through its interaction with viral phosphoprotein P. J. Virol. 2015, 89, 1640-1651. [CrossRef]

120. Gao, C.; Ma, C.; Wang, H.; Zhong, H.; Zang, J.; Zhong, R.; He, F.; Yang, D. Intrinsic disorder in protein domains contributes to both organism complexity and clade-specific functions. Sci. Rep. 2021, 11, 2985. [CrossRef]

121. Nikolic, J.; Civas, A.; Lama, Z.; Lagaudrière-Gesbert, C.; Blondel, D. Rabies Virus Infection Induces the Formation of Stress Granules Closely Connected to the Viral Factories. PLoS Pathog. 2016, 12, e1005942. [CrossRef] [PubMed]

122. Carromeu, C.; Simabuco, F.M.; Tamura, R.E.; Farinha Arcieri, L.E.; Ventura, A.M. Intracellular localization of human respiratory syncytial virus L protein. Arch. Virol. 2007, 152, 2259-2263. [CrossRef] [PubMed]

123. García-Barreno, B.; Delgado, T.; Melero, J.A. Identification of protein regions involved in the interaction of human respiratory syncytial virus phosphoprotein and nucleoprotein: Significance for nucleocapsid assembly and formation of cytoplasmic inclusions. J. Virol. 1996, 70, 801-808. [CrossRef] [PubMed]

124. Santangelo, P.J.; Bao, G. Dynamics of filamentous viral RNPs prior to egress. Nucleic Acids Res. 2007, 35, 3602-3611. [CrossRef]

125. Weber, E.; Humbert, B.; Streckert, H.J.; Werchau, H. Nonstructural protein 2 (NS2) of respiratory syncytial virus (RSV) detected by an antipeptide serum. Respiration 1995, 62, 27-33. [CrossRef]

126. Ghildyal, R.; Mills, J.; Murray, M.; Vardaxis, N.; Meanger, J. Respiratory syncytial virus matrix protein associates with nucleocapsids in infected cells. J. Gen. Virol. 2002, 83, 753-757. [CrossRef]

127. Munday, D.C.; Wu, W.; Smith, N.; Fix, J.; Noton, S.L.; Galloux, M.; Touzelet, O.; Armstrong, S.D.; Dawson, J.M.; Aljabr, W.; et al. Interactome analysis of the human respiratory syncytial virus RNA polymerase complex identifies protein chaperones as important cofactors that promote L-protein stability and RNA synthesis. J. Virol. 2015, 89, 917-930. [CrossRef] [PubMed]

128. Radhakrishnan, A.; Yeo, D.; Brown, G.; Myaing, M.Z.; Iyer, L.R.; Fleck, R.; Tan, B.-H.; Aitken, J.; Sanmun, D.; Tang, K.; et al Protein analysis of purified respiratory syncytial virus particles reveals an important role for heat shock protein 90 in virus particle assembly. Mol. Cell. Proteom. 2010, 9, 1829-1848. [CrossRef]

129. Ravi, L.I.; Tan, T.J.; Tan, B.H.; Sugrue, R.J. Virus-induced activation of the rac1 protein at the site of respiratory syncytial virus assembly is a requirement for virus particle assembly on infected cells. Virology 2021, 557, 86-99. [CrossRef]

130. Jeffree, C.E.; Brown, G.; Aitken, J.; Su-Yin, D.Y.; Tan, B.-H.; Sugrue, R.J. Ultrastructural analysis of the interaction between F-actin and respiratory syncytial virus during virus assembly. Virology 2007, 369, 309-323. [CrossRef]

131. Kipper, S.; Hamad, S.; Caly, L.; Avrahami, D.; Bacharach, E.; Jans, D.A.; Gerber, D.; Bajorek, M. New host factors important for respiratory syncytial virus (RSV) replication revealed by a novel microfluidics screen for interactors of matrix (M) protein. Mol. Cell. Proteom. 2015, 14, 532-543. [CrossRef] [PubMed]

132. Lifland, A.W.; Jung, J.; Alonas, E.; Zurla, C.; Crowe, J.E.; Santangelo, P.J. Human respiratory syncytial virus nucleoprotein and inclusion bodies antagonize the innate immune response mediated by MDA5 and MAVS. J. Virol. 2012, 86, 8245-8258. [CrossRef]

133. Freibaum, B.D.; Messing, J.; Yang, P.; Kim, H.J.; Taylor, J.P. High-fidelity reconstitution of stress granules and nucleoli in mammalian cellular lysate. J. Cell Biol. 2021, 220. [CrossRef] [PubMed]

134. García, J.; García-Barreno, B.; Vivo, A.; Melero, J.A. Cytoplasmic inclusions of respiratory syncytial virus-infected cells: Formation of inclusion bodies in transfected cells that coexpress the nucleoprotein, the phosphoprotein, and the 22K protein. Virology 1993, 195, 243-247. [CrossRef]

135. Spehner, D.; Drillien, R.; Howley, P.M. The assembly of the measles virus nucleoprotein into nucleocapsid-like particles is modulated by the phosphoprotein. Virology 1997, 232, 260-268. [CrossRef] [PubMed]

136. Tawara, J.T.; Goodman, J.R.; Imagawa, D.T.; Adams, J.M. Fine structure of cellular inclusions in experimental measles. Virology 1961, 14, 410-416. [CrossRef]

137. Pfaller, C.K.; Radeke, M.J.; Cattaneo, R.; Samuel, C.E. Measles virus C protein impairs production of defective copyback double-stranded viral RNA and activation of protein kinase R. J. Virol. 2014, 88, 456-468. [CrossRef] [PubMed]

138. Ma, D.; George, C.X.; Nomburg, J.L.; Pfaller, C.K.; Cattaneo, R.; Samuel, C.E. Upon Infection, Cellular WD Repeat-Containing Protein 5 (WDR5) Localizes to Cytoplasmic Inclusion Bodies and Enhances Measles Virus Replication. J. Virol. 2018, 92. [CrossRef] 
139. Pfaller, C.K.; Bloyet, L.-M.; Donohue, R.C.; Huff, A.L.; Bartemes, W.P.; Yousaf, I.; Urzua, E.; Clavière, M.; Zachary, M.; de Masson d'Autume, V.; et al. The C Protein Is Recruited to Measles Virus Ribonucleocapsids by the Phosphoprotein. J. Virol. 2020, 94. [CrossRef]

140. Longhi, S.; Receveur-Bréchot, V.; Karlin, D.; Johansson, K.; Darbon, H.; Bhella, D.; Yeo, R.; Finet, S.; Canard, B. The C-terminal domain of the measles virus nucleoprotein is intrinsically disordered and folds upon binding to the C-terminal moiety of the phosphoprotein. J. Biol. Chem. 2003, 278, 18638-18648. [CrossRef]

141. Schoehn, G.; Mavrakis, M.; Albertini, A.; Wade, R.; Hoenger, A.; Ruigrok, R.W.H. The 12 A structure of trypsin-treated measles virus N-RNA. J. Mol. Biol. 2004, 339, 301-312. [CrossRef]

142. Jensen, M.R.; Communie, G.; Ribeiro, E.A.; Martinez, N.; Desfosses, A.; Salmon, L.; Mollica, L.; Gabel, F.; Jamin, M.; Longhi, S.; et al. Intrinsic disorder in measles virus nucleocapsids. Proc. Natl. Acad. Sci. USA 2011, 108, 9839-9844. [CrossRef] [PubMed]

143. Desfosses, A.; Goret, G.; Farias Estrozi, L.; Ruigrok, R.W.H.; Gutsche, I. Nucleoprotein-RNA orientation in the measles virus nucleocapsid by three-dimensional electron microscopy. J. Virol. 2011, 85, 1391-1395. [CrossRef] [PubMed]

144. Gely, S.; Lowry, D.F.; Bernard, C.; Jensen, M.R.; Blackledge, M.; Costanzo, S.; Bourhis, J.-M.; Darbon, H.; Daughdrill, G.; Longhi, $\mathrm{S}$. Solution structure of the C-terminal $\mathrm{X}$ domain of the measles virus phosphoprotein and interaction with the intrinsically disordered C-terminal domain of the nucleoprotein. J. Mol. Recognit. 2010, 23, 435-447. [CrossRef] [PubMed]

145. Milles, S.; Jensen, M.R.; Lazert, C.; Guseva, S.; Ivashchenko, S.; Communie, G.; Maurin, D.; Gerlier, D.; Ruigrok, R.W.H.; Blackledge, M. An ultraweak interaction in the intrinsically disordered replication machinery is essential for measles virus function. Sci. Adv. 2018, 4, eaat7778. [CrossRef]

146. Abdella, R.; Aggarwal, M.; Okura, T.; Lamb, R.A.; He, Y. Structure of a paramyxovirus polymerase complex reveals a unique methyltransferase-CTD conformation. Proc. Natl. Acad. Sci. USA 2020, 117, 4931-4941. [CrossRef] [PubMed]

147. Guryanov, S.G.; Liljeroos, L.; Kasaragod, P.; Kajander, T.; Butcher, S.J. Crystal Structure of the Measles Virus Nucleoprotein Core in Complex with an N-Terminal Region of Phosphoprotein. J. Virol. 2015, 90, 2849-2857. [CrossRef]

148. Du Pont, V.; Jiang, Y.; Plemper, R.K. Bipartite interface of the measles virus phosphoprotein X domain with the large polymerase protein regulates viral polymerase dynamics. PLoS Pathog. 2019, 15, e1007995. [CrossRef]

149. Longhi, S.; Bloyet, L.-M.; Gianni, S.; Gerlier, D. How order and disorder within paramyxoviral nucleoproteins and phosphoproteins orchestrate the molecular interplay of transcription and replication. Cell. Mol. Life Sci. 2017, 74, 3091-3118. [CrossRef]

150. Brunel, J.; Chopy, D.; Dosnon, M.; Bloyet, L.-M.; Devaux, P.; Urzua, E.; Cattaneo, R.; Longhi, S.; Gerlier, D. Sequence of events in measles virus replication: Role of phosphoprotein-nucleocapsid interactions. J. Virol. 2014, 88, 10851-10863. [CrossRef]

151. Bloyet, L.-M.; Brunel, J.; Dosnon, M.; Hamon, V.; Erales, J.; Gruet, A.; Lazert, C.; Bignon, C.; Roche, P.; Longhi, S.; et al. Modulation of Re-initiation of Measles Virus Transcription at Intergenic Regions by PXD to NTAIL Binding Strength. PLoS Pathog. 2016, 12, e1006058. [CrossRef]

152. Katoh, H.; Kubota, T.; Kita, S.; Nakatsu, Y.; Aoki, N.; Mori, Y.; Maenaka, K.; Takeda, M.; Kidokoro, M. Heat shock protein 70 regulates degradation of the mumps virus phosphoprotein via the ubiquitin-proteasome pathway. J. Virol. 2015, 89, 3188-3199. [CrossRef] [PubMed]

153. Zhang, S.; Jiang, Y.; Cheng, Q.; Zhong, Y.; Qin, Y.; Chen, M. Inclusion Body Fusion of Human Parainfluenza Virus Type 3 Regulated by Acetylated $\alpha$-Tubulin Enhances Viral Replication. J. Virol. 2017, 91. [CrossRef]

154. Li, Y.; Zhang, C.; Lu, N.; Deng, X.; Zang, G.; Zhang, S.; Tang, H.; Zhang, G. Involvement of Actin-Regulating Factor Cofilin in the Inclusion Body Formation and RNA Synthesis of Human Parainfluenza Virus Type 3 via Interaction With the Nucleoprotein. Front. Microbiol. 2019, 10, 95. [CrossRef]

155. Carlos, T.S.; Young, D.F.; Schneider, M.; Simas, J.P.; Randall, R.E. Parainfluenza virus 5 genomes are located in viral cytoplasmic bodies whilst the virus dismantles the interferon-induced antiviral state of cells. J. Gen. Virol. 2009, 90, 2147-2156. [CrossRef]

156. Goldsmith, C.S.; Whistler, T.; Rollin, P.E.; Ksiazek, T.G.; Rota, P.A.; Bellini, W.J.; Daszak, P.; Wong, K.; Shieh, W.-J.; Zaki, S.R. Elucidation of Nipah virus morphogenesis and replication using ultrastructural and molecular approaches. Virus Res. 2003, 92, 89-98. [CrossRef]

157. Becker, S.; Rinne, C.; Hofsäss, U.; Klenk, H.D.; Mühlberger, E. Interactions of Marburg virus nucleocapsid proteins. Virology 1998, 249, 406-417. [CrossRef]

158. Bamberg, S.; Kolesnikova, L.; Möller, P.; Klenk, H.-D.; Becker, S. VP24 of Marburg virus influences formation of infectious particles. J. Virol. 2005, 79, 13421-13433. [CrossRef] [PubMed]

159. Groseth, A.; Charton, J.E.; Sauerborn, M.; Feldmann, F.; Jones, S.M.; Hoenen, T.; Feldmann, H. The Ebola virus ribonucleoprotein complex: A novel VP30-L interaction identified. Virus Res. 2009, 140, 8-14. [CrossRef] [PubMed]

160. Shu, T.; Gan, T.; Bai, P.; Wang, X.; Qian, Q.; Zhou, H.; Cheng, Q.; Qiu, Y.; Yin, L.; Zhong, J.; et al. Ebola virus VP35 has novel NTPase and helicase-like activities. Nucleic Acids Res. 2019, 47, 5837-5851. [CrossRef]

161. Woolsey, C.; Menicucci, A.R.; Cross, R.W.; Luthra, P.; Agans, K.N.; Borisevich, V.; Geisbert, J.B.; Mire, C.E.; Fenton, K.A.; Jankeel, A.; et al. A VP35 Mutant Ebola Virus Lacks Virulence but Can Elicit Protective Immunity to Wild-Type Virus Challenge. Cell Rep. 2019, 28, 3032-3046.e6. [CrossRef]

162. Huang, Y.; Xu, L.; Sun, Y.; Nabel, G.J. The Assembly of Ebola Virus Nucleocapsid Requires Virion-Associated Proteins 35 and 24 and Posttranslational Modification of Nucleoprotein. Mol. Cell 2002, 10, 307-316. [CrossRef]

163. Mateo, M.; Carbonnelle, C.; Martinez, M.J.; Reynard, O.; Page, A.; Volchkova, V.A.; Volchkov, V.E. Knockdown of Ebola virus VP24 impairs viral nucleocapsid assembly and prevents virus replication. J. Infect. Dis. 2011, 204 (Suppl. 3), S892-S896. [CrossRef] 
164. Zhang, A.P.P.; Bornholdt, Z.A.; Liu, T.; Abelson, D.M.; Lee, D.E.; Li, S.; Woods, V.L.; Saphire, E.O. The ebola virus interferon antagonist VP24 directly binds STAT1 and has a novel, pyramidal fold. PLoS Pathog. 2012, 8, e1002550. [CrossRef] [PubMed]

165. Watt, A.; Moukambi, F.; Banadyga, L.; Groseth, A.; Callison, J.; Herwig, A.; Ebihara, H.; Feldmann, H.; Hoenen, T. A novel life cycle modeling system for Ebola virus shows a genome length-dependent role of VP24 in virus infectivity. J. Virol. 2014, 88, 10511-10524. [CrossRef]

166. Miyake, T.; Farley, C.M.; Neubauer, B.E.; Beddow, T.P.; Hoenen, T.; Engel, D.A. Ebola Virus Inclusion Body Formation and RNA Synthesis Are Controlled by a Novel Domain of Nucleoprotein Interacting with VP35. J. Virol. 2020, 94. [CrossRef]

167. Modrof, J.; Möritz, C.; Kolesnikova, L.; Konakova, T.; Hartlieb, B.; Randolf, A.; Mühlberger, E.; Becker, S. Phosphorylation of Marburg virus VP30 at serines 40 and 42 is critical for its interaction with NP inclusions. Virology 2001, 287, 171-182. [CrossRef] [PubMed]

168. Martinez, M.J.; Volchkova, V.A.; Raoul, H.; Alazard-Dany, N.; Reynard, O.; Volchkov, V.E. Role of VP30 phosphorylation in the Ebola virus replication cycle. J. Infect. Dis. 2011, 204 (Suppl. 3), S934-S940. [CrossRef]

169. Lier, C.; Becker, S.; Biedenkopf, N. Dynamic phosphorylation of Ebola virus VP30 in NP-induced inclusion bodies. Virology 2017, 512, 39-47. [CrossRef] [PubMed]

170. Kruse, T.; Biedenkopf, N.; Hertz, E.P.T.; Dietzel, E.; Stalmann, G.; López-Méndez, B.; Davey, N.E.; Nilsson, J.; Becker, S. The Ebola Virus Nucleoprotein Recruits the Host PP2A-B56 Phosphatase to Activate Transcriptional Support Activity of VP30. Mol. Cell 2018, 69, 136-145.e6. [CrossRef] [PubMed]

171. Noda, T.; Ebihara, H.; Muramoto, Y.; Fujii, K.; Takada, A.; Sagara, H.; Kim, J.H.; Kida, H.; Feldmann, H.; Kawaoka, Y. Assembly and budding of Ebolavirus. PLoS Pathog. 2006, 2, e99. [CrossRef]

172. Dolnik, O.; Kolesnikova, L.; Welsch, S.; Strecker, T.; Schudt, G.; Becker, S. Interaction with Tsg101 is necessary for the efficient transport and release of nucleocapsids in marburg virus-infected cells. PLoS Pathog. 2014, 10, e1004463. [CrossRef]

173. Watanabe, S.; Noda, T.; Halfmann, P.; Jasenosky, L.; Kawaoka, Y. Ebola virus (EBOV) VP24 inhibits transcription and replication of the EBOV genome. J. Infect. Dis. 2007, 196 (Suppl. 2), S284-S290. [CrossRef]

174. Noda, T.; Kolesnikova, L.; Becker, S.; Kawaoka, Y. The importance of the NP: VP35 ratio in Ebola virus nucleocapsid formation. J. Infect. Dis. 2011, 204 (Suppl. 3), S878-S883. [CrossRef]

175. Noda, T.; Halfmann, P.; Sagara, H.; Kawaoka, Y. Regions in Ebola virus VP24 that are important for nucleocapsid formation. J. Infect. Dis. 2007, 196 (Suppl. 2), S247-S250. [CrossRef]

176. Banadyga, L.; Hoenen, T.; Ambroggio, X.; Dunham, E.; Groseth, A.; Ebihara, H. Ebola virus VP24 interacts with NP to facilitate nucleocapsid assembly and genome packaging. Sci. Rep. 2017, 7, 7698. [CrossRef]

177. Takamatsu, Y.; Kolesnikova, L.; Schauflinger, M.; Noda, T.; Becker, S. The Integrity of the YxxL Motif of Ebola Virus VP24 Is Important for the Transport of Nucleocapsid-Like Structures and for the Regulation of Viral RNA Synthesis. J. Virol. 2020, 94. [CrossRef] [PubMed]

178. Schudt, G.; Dolnik, O.; Kolesnikova, L.; Biedenkopf, N.; Herwig, A.; Becker, S. Transport of Ebolavirus Nucleocapsids Is Dependent on Actin Polymerization: Live-Cell Imaging Analysis of Ebolavirus-Infected Cells. J. Infect. Dis. 2015, 212 (Suppl. 2), S160-S166. [CrossRef]

179. Su, J.M.; Wilson, M.Z.; Samuel, C.E.; Ma, D. Formation and Function of Liquid-Like Viral Factories in Negative-Sense SingleStranded RNA Virus Infections. Viruses 2021, 13, 126. [CrossRef] [PubMed]

180. Nevers, Q.; Albertini, A.A.; Lagaudrière-Gesbert, C.; Gaudin, Y. Negri bodies and other virus membrane-less replication compartments. Biochim. Biophys. Acta Mol. Cell Res. 2020, 1867, 118831. [CrossRef] [PubMed]

181. Geisbert, T.W.; Jahrling, P.B. Differentiation of filoviruses by electron microscopy. Virus Research 1995, 39, 129-150. [CrossRef]

182. Kolesnikova, L.; Bugany, H.; Klenk, H.-D.; Becker, S. VP40, the matrix protein of Marburg virus, is associated with membranes of the late endosomal compartment. J. Virol. 2002, 76, 1825-1838. [CrossRef]

183. Dolnik, O.; Volchkova, V.A.; Escudero-Perez, B.; Lawrence, P.; Klenk, H.-D.; Volchkov, V.E. Shedding of Ebola Virus Surface Glycoprotein Is a Mechanism of Self-regulation of Cellular Cytotoxicity and Has a Direct Effect on Virus Infectivity. J. Infect. Dis. 2015, 212 (Suppl. 2), S322-S328. [CrossRef]

184. Wendt, L.; Brandt, J.; Bodmer, B.S.; Reiche, S.; Schmidt, M.L.; Traeger, S.; Hoenen, T. The Ebola Virus Nucleoprotein Recruits the Nuclear RNA Export Factor NXF1 into Inclusion Bodies to Facilitate Viral Protein Expression. Cells 2020, 9, 187. [CrossRef] [PubMed]

185. Brandt, J.; Wendt, L.; Bodmer, B.S.; Mettenleiter, T.C.; Hoenen, T. The Cellular Protein CAD is Recruited into Ebola Virus Inclusion Bodies by the Nucleoprotein NP to Facilitate Genome Replication and Transcription. Cells 2020, 9, 1126. [CrossRef] [PubMed]

186. Nelson, E.V.; Schmidt, K.M.; Deflubé, L.R.; Doğanay, S.; Banadyga, L.; Olejnik, J.; Hume, A.J.; Ryabchikova, E.; Ebihara, H.; Kedersha, N.; et al. Ebola Virus Does Not Induce Stress Granule Formation during Infection and Sequesters Stress Granule Proteins within Viral Inclusions. J. Virol. 2016, 90, 7268-7284. [CrossRef] [PubMed]

187. Le Sage, V.; Cinti, A.; McCarthy, S.; Amorim, R.; Rao, S.; Daino, G.L.; Tramontano, E.; Branch, D.R.; Mouland, A.J. Ebola virus VP35 blocks stress granule assembly. Virology 2017, 502, 73-83. [CrossRef] [PubMed]

188. Lee, J.E.; Cathey, P.I.; Wu, H.; Parker, R.; Voeltz, G.K. Endoplasmic reticulum contact sites regulate the dynamics of membraneless organelles. Science 2020, 367. [CrossRef] [PubMed]

189. Patel, A.; Malinovska, L.; Saha, S.; Wang, J.; Alberti, S.; Krishnan, Y.; Hyman, A.A. ATP as a biological hydrotrope. Science 2017, 356, 753-756. [CrossRef] 
190. Zhao, Y.G.; Zhang, H. Phase Separation in Membrane Biology: The Interplay between Membrane-Bound Organelles and Membraneless Condensates. Dev. Cell 2020, 55, 30-44. [CrossRef] [PubMed]

191. Noda, T.; Murakami, S.; Nakatsu, S.; Imai, H.; Muramoto, Y.; Shindo, K.; Sagara, H.; Kawaoka, Y. Importance of the 1+7 configuration of ribonucleoprotein complexes for influenza A virus genome packaging. Nat. Commun. 2018, 9, 54. [CrossRef]

192. Muramoto, Y.; Takada, A.; Fujii, K.; Noda, T.; Iwatsuki-Horimoto, K.; Watanabe, S.; Horimoto, T.; Kida, H.; Kawaoka, Y. Hierarchy among viral RNA (vRNA) segments in their role in vRNA incorporation into influenza A virions. J. Virol. 2006, 80, $2318-2325$. [CrossRef]

193. Fournier, E.; Moules, V.; Essere, B.; Paillart, J.-C.; Sirbat, J.-D.; Cavalier, A.; Rolland, J.-P.; Thomas, D.; Lina, B.; Isel, C.; et al. Interaction network linking the human H3N2 influenza A virus genomic RNA segments. Vaccine 2012, 30, 7359-7367. [CrossRef]

194. Fournier, E.; Moules, V.; Essere, B.; Paillart, J.-C.; Sirbat, J.-D.; Isel, C.; Cavalier, A.; Rolland, J.-P.; Thomas, D.; Lina, B.; et al. A supramolecular assembly formed by influenza A virus genomic RNA segments. Nucleic Acids Res. 2012, 40, 2197-2209. [CrossRef]

195. Lakdawala, S.S.; Wu, Y.; Wawrzusin, P.; Kabat, J.; Broadbent, A.J.; Lamirande, E.W.; Fodor, E.; Altan-Bonnet, N.; Shroff, H.; Subbarao, K. Influenza a virus assembly intermediates fuse in the cytoplasm. PLoS Pathog. 2014, 10, e1003971. [CrossRef]

196. De Castro Martin, I.F.; Fournier, G.; Sachse, M.; Pizarro-Cerda, J.; Risco, C.; Naffakh, N. Influenza virus genome reaches the plasma membrane via a modified endoplasmic reticulum and Rab11-dependent vesicles. Nat. Commun. 2017, 8, 1396. [CrossRef]

197. Wu, X.; Qi, X.; Liang, M.; Li, C.; Cardona, C.J.; Li, D.; Xing, Z. Roles of viroplasm-like structures formed by nonstructural protein NSs in infection with severe fever with thrombocytopenia syndrome virus. FASEB J. 2014, 28, 2504-2516. [CrossRef] [PubMed]

198. Fontana, J.; López-Montero, N.; Elliott, R.M.; Fernández, J.J.; Risco, C. The unique architecture of Bunyamwera virus factories around the Golgi complex. Cell. Microbiol. 2008, 10, 2012-2028. [CrossRef] [PubMed]

199. Baird, N.L.; York, J.; Nunberg, J.H. Arenavirus infection induces discrete cytosolic structures for RNA replication. J. Virol. 2012, 86, 11301-11310. [CrossRef]

200. Bartok, E.; Hartmann, G. Immune Sensing Mechanisms that Discriminate Self from Altered Self and Foreign Nucleic Acids. Immunity 2020, 53, 54-77. [CrossRef] [PubMed]

201. Chatterjee, S.; Basler, C.F.; Amarasinghe, G.K.; Leung, D.W. Molecular Mechanisms of Innate Immune Inhibition by NonSegmented Negative-Sense RNA Viruses. J. Mol. Biol. 2016, 428, 3467-3482. [CrossRef] [PubMed]

202. Gerlier, D.; Lyles, D.S. Interplay between innate immunity and negative-strand RNA viruses: Towards a rational model. Microbiol. Mol. Biol. Rev. 2011, 75, 468-490. [CrossRef]

203. Chelbi-Alix, M.K.; Vidy, A.; El Bougrini, J.; Blondel, D. Rabies viral mechanisms to escape the IFN system: The viral protein P interferes with IRF-3, Stat1, and PML nuclear bodies. J. Interferon Cytokine Res. 2006, 26, 271-280. [CrossRef] [PubMed]

204. Brzózka, K.; Finke, S.; Conzelmann, K.-K. Identification of the rabies virus alpha/beta interferon antagonist: Phosphoprotein P interferes with phosphorylation of interferon regulatory factor 3. J. Virol. 2005, 79, 7673-7681. [CrossRef] [PubMed]

205. Basler, C.F.; Mikulasova, A.; Martinez-Sobrido, L.; Paragas, J.; Mühlberger, E.; Bray, M.; Klenk, H.-D.; Palese, P.; García-Sastre, A. The Ebola virus VP35 protein inhibits activation of interferon regulatory factor 3. J. Virol. 2003, 77, 7945-7956. [CrossRef] [PubMed]

206. Basler, C.F.; Amarasinghe, G.K. Evasion of interferon responses by Ebola and Marburg viruses. J. Interferon Cytokine Res. 2009, 29, 511-520. [CrossRef]

207. Prins, K.C.; Cárdenas, W.B.; Basler, C.F. Ebola virus protein VP35 impairs the function of interferon regulatory factor-activating kinases IKKepsilon and TBK-1. J. Virol. 2009, 83, 3069-3077. [CrossRef]

208. Hartman, A.L.; Bird, B.H.; Towner, J.S.; Antoniadou, Z.-A.; Zaki, S.R.; Nichol, S.T. Inhibition of IRF-3 activation by VP35 is critical for the high level of virulence of ebola virus. J. Virol. 2008, 82, 2699-2704. [CrossRef]

209. Cárdenas, W.B.; Loo, Y.-M.; Gale, M.; Hartman, A.L.; Kimberlin, C.R.; Martínez-Sobrido, L.; Saphire, E.O.; Basler, C.F. Ebola virus VP35 protein binds double-stranded RNA and inhibits alpha/beta interferon production induced by RIG-I signaling. J. Virol. 2006, 80, 5168-5178. [CrossRef]

210. Schümann, M.; Gantke, T.; Mühlberger, E. Ebola virus VP35 antagonizes PKR activity through its C-terminal interferon inhibitory domain. J. Virol. 2009, 83, 8993-8997. [CrossRef] [PubMed]

211. Wu, X.; Qi, X.; Qu, B.; Zhang, Z.; Liang, M.; Li, C.; Cardona, C.J.; Li, D.; Xing, Z. Evasion of antiviral immunity through sequestering of TBK1/IKKع/IRF3 into viral inclusion bodies. J. Virol. 2014, 88, 3067-3076. [CrossRef] [PubMed]

212. Jobe, F.; Simpson, J.; Hawes, P.; Guzman, E.; Bailey, D. Respiratory Syncytial Virus Sequesters NF-кB Subunit p65 to Cytoplasmic Inclusion Bodies To Inhibit Innate Immune Signaling. J. Virol. 2020, 94. [CrossRef]

213. Fricke, J.; Koo, L.Y.; Brown, C.R.; Collins, P.L. p38 and OGT sequestration into viral inclusion bodies in cells infected with human respiratory syncytial virus suppresses MK2 activities and stress granule assembly. J. Virol. 2013, 87, 1333-1347. [CrossRef]

214. Onomoto, K.; Jogi, M.; Yoo, J.-S.; Narita, R.; Morimoto, S.; Takemura, A.; Sambhara, S.; Kawaguchi, A.; Osari, S.; Nagata, K.; et al. Critical role of an antiviral stress granule containing RIG-I and PKR in viral detection and innate immunity. PLoS ONE 2012, 7, e43031. [CrossRef]

215. Dinh, P.X.; Beura, L.K.; Das, P.B.; Panda, D.; Das, A.; Pattnaik, A.K. Induction of stress granule-like structures in vesicular stomatitis virus-infected cells. J. Virol. 2013, 87, 372-383. [CrossRef] [PubMed]

216. Hong, Y.; Bai, M.; Qi, X.; Li, C.; Liang, M.; Li, D.; Cardona, C.J.; Xing, Z. Suppression of the IFN- $\alpha$ and $-\beta$ Induction through Sequestering IRF7 into Viral Inclusion Bodies by Nonstructural Protein NSs in Severe Fever with Thrombocytopenia Syndrome Bunyavirus Infection. J. Immunol. 2019, 202, 841-856. [CrossRef] [PubMed] 
217. Kitagawa, Y.; Sakai, M.; Shimojima, M.; Saijo, M.; Itoh, M.; Gotoh, B. Nonstructural protein of severe fever with thrombocytopenia syndrome phlebovirus targets STAT2 and not STAT1 to inhibit type I interferon-stimulated JAK-STAT signaling. Microbes Infect. 2018, 20, 360-368. [CrossRef]

218. Ning, Y.-J.; Feng, K.; Min, Y.-Q.; Cao, W.-C.; Wang, M.; Deng, F.; Hu, Z.; Wang, H. Disruption of type I interferon signaling by the nonstructural protein of severe fever with thrombocytopenia syndrome virus via the hijacking of STAT2 and STAT1 into inclusion bodies. J. Virol. 2015, 89, 4227-4236. [CrossRef] [PubMed]

219. Santiago, F.W.; Covaleda, L.M.; Sanchez-Aparicio, M.T.; Silvas, J.A.; Diaz-Vizarreta, A.C.; Patel, J.R.; Popov, V.; Yu, X.; GarcíaSastre, A.; Aguilar, P.V. Hijacking of RIG-I signaling proteins into virus-induced cytoplasmic structures correlates with the inhibition of type I interferon responses. J. Virol. 2014, 88, 4572-4585. [CrossRef] 